\title{
Continuances in the Cook County Criminal Courts
}

\author{
Laura Banfield and C. David Anderson
}

Many judges and lawyers whose suggestions we solicited in the early days of this project responded with some perplexity: "Continuances? They're not interesting, so why study them?" We explained that we were concerned with continuances (postponements of a court action to a subsequent date) not as a legal phenomenon, but rather with their impact on the system of criminal justice. We wanted to investigate the complaints of some observers that the volume of continuances in the Cook County criminal courts is excessively high; that defendants use continuances to defeat or delay prosecution; and that more stringent control of continuances on the part of the courts would yield both an increase in convictions and a reduction of costs in terms of police, witness, and court time. At this point, some of our judges and attorneys agreed that continuances might be worth studying. Others insisted that we were on the wrong track. "There aren't all that many continuances, and most of them are necessary," they said. "Anyway, continuances are a nuisance, but it's nonsense to pretend that they handcuff the police or infringe anyone's constitutional rights, so why worry?" These contrasting views on the part of those closest to the court system confirmed our suspicion that an empirical investigation of the role of continuances in the Cook County criminal courts might be of some utility, if only to determine whether there is indeed a problem.

\section{Background: Dimensions of the Problem}

With all respect for the difficulty of organizing what we know before we know it, it may be said that a decision to study continuances in

Laura Banfield, J.D. 1967, University of Chicago Law School; G. David Anderson, J.D. 1967, University of Chicago Law School.

The authors would like to express their appreciation to the Center for Studies in Criminal Justice at the University of Chicago Law School for funding this study, to classmate, now Assistant Professor, Frank Zimring for his constant and intelligent counsel, and to Joseph Bentley in gathering the data, Angela Lane in programming and operating the computers, and Richard Chused in final editing. The authors also would like to acknowledge the cooperation and interest of the Chicago Police Department and the many judges, court officials, and attorneys who gave their time and experience to this study. 
criminal courts starts from three assumptions. First, we assume that there are some social costs associated with all continuances. Second, we recognize that the legal system regards some continuances as serving a social purpose which justifies their cost; continuances which serve no such purpose are presumably undesirable. Third, we must confront the framework of rules, both of law and of practice, by which the use of continuances is regulated. It may be helpful to catalog the components of these considerations in some detail: what are the potential uses and abuses of continuances; and what are the rules whose effectiveness we want to gauge?

\section{A. Continuance Costs}

Perhaps because serious interest in the operations of the criminal courts has only begun to emerge, the consequences of delay in criminal proceedings have not received the attention which has been devoted to the problem in the context of civil litigation. ${ }^{1}$ It has, of course, long been understood that the legal system accords a special importance to speed in the administration of criminal justice; indeed, that understanding may have contributed to a general belief that criminal courts are not afflicted with a problem of delay. Recent studies, however, most prominently those of the President's Commission, ${ }^{2}$ have cast doubt on this premise, and another look at the costs associated with delay in criminal proceedings seems justified.

1. Time and money. The most obvious cost of continuances is the time and money of those involved in the trial of criminal cases. ${ }^{3}$ While

1 Among the best known treatments of delay in civil litigation is H. ZEISEL, H. KALVEN \& B. Bughinolz, Delay in the Court (1959). See also Proceedings of the U.S. AtTorney General's Conference on Court Congestion and Delay in Litigation (May 21-22, 1956), and the report of proceedings under the same name in a second conference held June 16 and 17,1958 . The latter, at $213-45$, contains a bibliography of the voluminous literature on the subject, most of it devoted to civil litigation.

2 The President's Commission on the District of Columbia courts found excessive delay at all levels of the system and considered the problem in some detail. 1 REPORT OF THE Prestdent's Commission on Crime IN the District of Columbla 255-70 (1966). The national study treated delay as a general problem, recommending changes in court administration and scheduling and drawing up a "model timetable" for the disposition of criminal cases. The Presment's Commission on LAw Enforcemint and Administration of JUSTICE, TASK Force REPORT: ThE COURTS 80-90 (1967) [hereinafter cited as TASK FORCE RERORT].

3 The problem of court delay is commonly treated in connection with court congestion in terms of the backlog or "waiting list" in the scheduling and hearing of cases after the parties are ready for trial. "Waiting list" delay must be distinguished from delay occasioned by continuances, since continuances reflect the parties' need for more time. Court congestion figures as a source of continuances in two aspects: first, the court because it is too busy may have to continue cases; and second, overly busy judges may be more liberal in granting continuances than they otherwise would be. Whether attributable to a "waiting list" or to continuances, however, the consequences or costs of delay would 
some insist that continuances are necessary to enable judges to get through their overly long court calls, it is apparent that, since hearing motions for continuances and rescheduling cases takes time, continuances are more nearly a cause than a cure for court congestion. Nor is the argument that continuances save court time by facilitating plea bargaining and out of court "settlement" persuasive; it seems more likely that fewer or shorter continuances would speed up the bargaining process rather than throw cases back to court. Continuances are also a source of judicial inefficiency in scheduling cases; a judge, unable to anticipate how many of the cases on each day's call will proceed as scheduled, does not know whether he will be left with "dead time" on his hands.

Continuances also impose the burden of fruitless trips to court on witnesses and attorneys. The cost of such trips to the Police Department is measured both in the salaries paid to officers and in time taken away from police work. ${ }^{4}$ Private citizens incur these losses as well, since a day in court may often result in lost earnings. Although attorneys may receive payment for their time, many continuances, especially those requested by the opposing party, may remove the attorney from other tasks. All these costs are multiplied in Cook County by the noncentral location of most of the criminal courts. ${ }^{5}$ As will be explained below, these time and money costs to private witnesses and attorneys may eventually be translated into costs to the system of criminal justice when witnesses and attorneys who find trips to court overly burdensome decline to return.

2. "Justice delayed is justice denied." Continuances may compromise the fairness of criminal proceedings if a delayed trial has a different, and less just, outcome from a speedy one. Witnesses may die. Their memories may fade. Their testimony may become more vulnerable to cross-examination. They may be "worn out" by repeated trips to court and refuse to appear again, or become less cooperative. A cynic, or a

appear to be the same, so that the two phenomena need not be distinguished in a discussion of costs.

4 The Chicago Police Department was unable to supply data concerning the number of police man-hours spent in court and the cost to the Department of sending them. A rough measure may be found in the Department's decision, when it embarked on a program of paying officers who had to appear in court on off-duty days, to fix the rate of compensation at three hours time per court date. The three hours is itself an estimate of actual time spent in court. The Department assumed, since court calls are not staggered, that an appearance could take anywhere from one to six hours. Three hours' pay per appearance was deemed a reasonable compromise. The Department also assigns a "court sergeant" to many courts, whose duties include keeping a log of officers' appearances.

6 The Cook County Jail and Criminal Court building are both located southwest of the Chicago loop in an area not easily reached by public transportation. 
vigilant law enforcement officer, would add that opportunities for intimidating witnesses or bribing officials increase as a function of time. Although these consequences of delay can disadvantage either the prosecution or the defense, observers insist that "staleness" is far more likely to injure the prosecution, which is responsible for the production of most witnesses and has the burden of proving guilt beyond a reasonable doubt. Thus a prosecutor, aware that his case is growing weaker with the passage of time, may be forced to consent to a reduction of the charge or to end prosecution altogether. To those critical of the court system, "lost convictions" are the most significant cost of continuances.

Continuances also entail some sacrifice of the objective of speedy trial. Speedy trial is generally regarded as a protection to the defendant against the harassment of prolonged prosecution. Delay is especially costly to defendants detained for long periods of time awaiting trial. For some defendants the desire for a delayed rather than a speedy trial may outweigh the personal cost attendant to such delay. Nonetheless, lengthy proceedings produce costs to the legal system as a whole under any of the commonly accepted theories of penal sanction. From the standpoint of retribution, speedy trial is an adjunct of the need for finality; in order to maintain public confidence that the guilty are punished, the tension of incomplete determinations must be resolved as quickly as possible. A deterrence rationale also requires that delay be minimized; the deterrent efficacy of criminal sanctions is presumably diluted when their application is postponed and consequently made less certain. Even the rehabilitative ideal is best served when treatment of the offender is begun as soon as possible after commission of the offense. Thus, delay may or may not impose costs on the defendant, but it necessarily imposes costs on the system of criminal justice.

Another social cost of continuances is the cost of crimes committed by persons released on bail during the period of delay between arrest and trial, particularly if we hypothesize that professional criminals are most likely to be released on bail and are also most likely to manipulate continuances. Although interim crimes are commonly treated as a cost of the bail system, it seems more logical that only those crimes committed between arrest and "speedy trial" are costs of the bail system, while crimes committed during the period of delay are properly chargeable to continuances. The common sense statement of this academic calculation is that the longer it takes to get criminal cases to trial, the more dangerous bail release is going to look. To the extent that this extra margin of danger retards bail reform, continuances create the further cost of promoting pre-trial detention in non-continuance cases. 
3. Blind, but why so slow? Finally, delay in criminal courts may be unfortunate because it tarnishes the image of the system in the eyes of the community. The criminal law must not only do justice, but must also appear to do justice; even legitimate delay detracts from public confidence if its purpose is not understood. Delay may also lessen public willingness to cooperate with the police and court system. Witnesses "worn out" by repeated and, in their eyes, fruitless trips to court become disaffected and unwilling to "get involved" on future occasions. Attorneys may react in a similar fashion. Loss of citizen confidence and cooperation are important public relations costs of continuances. ${ }^{6}$

The costs outlined above are associated with all continuances, legitimate or otherwise. They are different in kind, and may not be of comparable importance. The task of estimating their magnitude poses a variety of problems. Some of them-the consequences of delay for the public image of criminal justice, and the costs of less-than-speedy trial to defendants and to the system as a whole-seem almost unmeasurable, at least within the confines of this study. Although not pursued here, studies of crimes committed by offenders released on bail might furnish an estimate of the costs caused by delay of released offenders' trials. A properly ambitious study might calculate the loss of court time and the number of police and witness hours in continued cases and so arrive at an index of the "time and money" costs of continuances. Most critical for the present purpose is the cost of continuances in terms of lost convictions, since this may be closely related to the question of the extent to which defendants do in fact use continuances to defeat or delay prosecution. Thus, this study concentrates upon witness costs and lost convictions-in part because other costs are harder to measure; in part because these costs are related to other problems with which the study is concerned; and in part because critics of the court system regard lost convictions as the most serious cost of continuances.

\section{B. The Uses of Continuances}

To say that all continuances impose costs is not, of course, to say that all continuances should be eliminated; some continuances serve a social purpose which outweighs their cost. Thus, the legal system deems legitimate those continuances which promote the interests of a fair hearing to both accused and prosecutor. Not all continuances serve this purpose, however; some portion reflect the exploitation of delay either for its own sake or as a tactic in litigation, while others are symptoms of "system overload"-too much work for too few judges and lawyers.

o The President's Commission emphasized the need for changes in court administration which would enhance public cooperation. TASR FORCE REPORT, supra note 2, at 90-91. 
Despite the risk of oversimplification, some classification of the many uses of continuances is necessary as a first step toward our ultimate goal of determining what proportion of the present volume of continuances in the Cook County criminal courts is attributable to the demands of fair hearing and what portions are chargeable to other factors.

I. "Fair hearing" continuances sanctioned by the legal system arise in a wide variety of situations. Often they are incidents of the defendant's procedural rights-the right to be represented by and to consult with counsel, for example, and the right to make pre-trial motions such as motions to dismiss or to suppress evidence. "Fair hearing" continuances may also stem from the demands of trial preparation; complex factual or legal situations, multiple defendants, missing witnesses, psychiatric examinations, pre-sentence investigations, and the like may result in a need for additional time on the part of either the prosecution or the defense. Finally, some allowance must be made for the unexpected or unavoidable. A lawyer may be ill or "held to trial in another cause"; a key witness may fail to appear; or a police officer may come to court with the wrong records. Even if the delay is caused by negligence rather than by unavoidable circumstances, the interests of a fair hearing may require a continuance.

In general, the volume of legitimate or "fair hearing" continuances might be expected to grow with modern developments in criminal procedure. Right to counsel decisions, for example, have expanded the proportion of defendants represented by counsel at earlier stages of the proceedings, while search and seizure cases have broadened the grounds on which motions to suppress may be based. ${ }^{7}$ Perhaps also as the criminal law crawls out of the courthouse basement, the time expended in investigating and preparing criminal cases will increase as well. This predicted growth in the volume of legitimate continuances seems likely, however, to be accompanied by increased difficulty in distinguishing legitimate from less legitimate continuances, and in controlling the latter, since "abuse" continuances often present themselves to the courts in the guise of legitimate motions.

2. "Abuse" continuances have no apparent social purpose; they do not promote, and may be designed to defeat, fair hearing and other social goals. The defendant or the prosecution may seek delay for many reasons. The defendant may simply want to stave off the inevitable, either because he hopes for a miracle, because he is a narcotics addict

7 The President's Commission study of the District of Columbia court system concluded that recent court decisions accounted for a good part of the increase in motions and in delay. I Report of the President's Commisston on Crime in the District of Columbia 264-66 (1966). 
afraid that his supply will be cut off, because he "doesn't want to go to County Jail in the summertime," 8 because he wants to earn money for his wife and children for as long as he can, or because jail tomorrow is thought preferable to jail today. Although the state has less interest in delay for its own sake, prosecutors in Chicago have been known to use continuances in cases where there is little chance of conviction as a device for "keeping the defendant off the street for a while."

In some situations continuances may represent the use of delay as a tactic in litigation. The defense may believe that delay will reduce the likelihood of conviction-that witnesses will be "worn out" and their testimony more vulnerable to cross-examination, or that their desire and that of the community for retribution will be less acute. Similarly, defense counsel may make dilatory motions which stand some small chance of success, perhaps to increase the size of his fee, or perhaps in the belief that he has a duty to his client to try everything. Either the state or the defendant may try to postpone trial of a case in the hope of favorable "settlement" through plea bargaining and charge reduction. Since bargaining could function without multiple continuances, social policy does not demand that they be tolerated for this reason.

Defense lawyers are also said to use continuances to collect their fees. Since it is thought to be difficult to collect fees once a case is concluded, particularly if the client is convicted and loses his job or goes to jail, lawyers may request a continuance "for professional reasons" if their fee has not been paid on the day scheduled for trial..$^{10}$

8 Such farfetched examples of continuance abuse do occur. One lawyer described a burglary case to the authors. A professional burglar, who had a bad narcotics habit, would be arrested, released on bond, and re-arrested about once a month for a new crime. By trial time six theft and burglary charges were outstanding against him. The attorney had already played along for the "usual number" of continuances, but the defendant desired to delay his prison term. Since the attorney had kept him out all winter, could he not do the same for summer? The attorney could and did, and after the trial in the fall the prison term was further delayed. Thirty days were obtained for dental work, and thirty more because the defendant wanted them. The whole process ended because the attorney was getting nervous over possible bail forfeiture: return of the bond guaranteed his fee.

9 For an account of the attempted use of the "sitting out period," combining prohibitively high bail with a long continuance, to keep members of the Blackstone Rangers (an all-Negro gang) off the street for a time, see Oaks \& Lehman, The Criminal Process of Cook County and the Indigent Defendant, 1966 ILL. L.F. 584, 669 n.I52.

10 The legal system does not recognize the "fee continuance" as a legitimate reason for delay, and perhaps for good reason, since one can imagine the incentive which this continuance offers to the defendant to commit additional crimes to get money to pay his lawyer. The President's Commission, while aware of this aspect of the problem, observed that there is some social interest in having as many defendants as possible represented by retained counsel and in making criminal law sufficiently profitable to attract practitioners. The Commission recommended some measure of control through judicial discretion-implying that the fee continuance should at least be brought out into the open- 
It is hardly surprising that judges and lawyers disagree on the prevalence of continuance abuse. Most are willing, off the record, to point to a few shady characters known for their devious ways. There is much dispute, however, as to what portion of the bar as a whole engages in these practices, and there is even less consensus as to what does or does not constitute continuance abuse. Interview results which amount to a compilation of rumors are helpful in telling us what may be happening; finding out what does happen and how often is a next step.

3. "System overload"- too many cases handled by too few judges and attorneys-is often said to be a reason for continuances. Assuming for a moment that "overload" exists to some degree in the Cook County criminal courts, the delay which it engenders cannot properly be labelled "abuse," since it may be inevitable despite the best intentions of all concerned. It is not, however, socially desirable; it contributes nothing to fair hearing and imposes all the costs associated with delay.

Court congestion, the traditional starting point for studies of delay in the court, is often offered as an explanation for continuances in the Chicago criminal courts. Although judges report that they sometimes do have to continue cases in which the parties have come to court prepared, the busyness of judges more frequently operates as an indirect cause of continuances; that is, judges whose schedules are too full are likely to be more liberal in granting continuances requested by the parties than they otherwise would be. Court congestion thus figures as a factor which contributes to the difficulty of controlling the level of continuances.

The busyness of lawyers is also said to account for a large number of continuances. The criminal bar in Chicago is small; a handful of lawyers handles a large number of cases. These lawyers, the argument goes, are inordinately busy, and are often forced to schedule many cases for one day, knowing that they will be prepared in only one or two and will have to continue the rest. Continuances which result from overconcentration of this kind must be distinguished from those which result from occasional miscalculation. The latter are properly "fair hearing" continuances, since the legal system must be prepared to tolerate accidental mis-steps. Knowing or deliberate busyness, by contrast, is a consequence of "overload." How much of the busy lawyer argument represents reality and how much represents rationalization

and perhaps also subsidies for "marginally indigent" clients to help them pay their lawyers. TASK FORCE REPORT, supra note 2, at 86. Excellent anecdotal material on fee continuances appears in M. MAYeR, The LAwYeR 161-62 (1967). New York practice is for the lawyer to request a continuance because he has been unable to locate his witness, "Mr. Green," while District of Columbia practice is to ask for a continuance "pursuant to Rule 1 of this court." 
is far from clear. Lawyers say that the criminal bar is small because most of the legal profession disdains criminal work, both because its image is less than clean and because it is poorly paid. The only way to make a living in criminal work, they say, is to handle a large volume of cases. A skeptic might doubt that the supply of lawyers willing to take criminal cases is in fact so inelastic, although it may be true that lawyers regard criminal work as a specialty to be left to specialists. A high volume of cases is characteristic of trial practice, civil as well as criminal; it does not necessarily follow, however, that taking away from lawyers the excess of cases which produces excess "busyness" would drive them out of business or raise their fees beyond the ability of clients to pay. Plainly the whole question of the market for legal services in the criminal field needs investigation, but at this point neither the degree of overconcentration nor its inevitability has been satisfactorily established.

The foregoing catalog of the uses and abuses of, reasons for, and causes of continuances is by no means exhaustive. It is arbitrary in that many continuances probably have multiple causes and because it ignores the gray areas; one man's dilatory motion may be another man's duty to his client. Moreover, the adversary system permits some use of delay as a tactic in litigation, subject to the court's discretion. Indeed, it could be said that within some ethical limits the lawyer's duty to his client encompasses a "duty of abuse," a duty to do what is in the interests of his client. The task of discriminating between "abuse" and "fair hearing" continuances and putting those whose social value is marginal into one category or the other is the province of the courts and the legal system, not of lawyers. The question then becomes whether the rules the system has laid down, and the means by which it enforces them, are adequate to control continuance abuse.

\section{Continuances and the Law}

The law on continuances is remarkably uninteresting. The constitutional dimensions are vague, and the statutory and case law of Illinois crystallized long ago into formulae whose substance has called forth little debate. Closer examination reveals the rules to be little more than guidelines for the exercise of trial court discretion; how much attention trial courts pay to these guidelines is another, and perhaps more significant, question.

Although the familiar constitutional guarantee of the right to speedy trial $^{11}$ has no express counterpart assuring the accused adequate time

11 U.S. Consr. amend. VI. The Illinois Constitution also guarantees the right to speedy trial. ILL. CoNsT. art. II, \& 9 (1870). 
to prepare his defense, such a right has been held implicit in the due process right to fair hearing. ${ }^{12}$ These constitutional limits posed by the right to speedy trial on the one hand, and to fair hearing on the other, are broad ones, however, for by and large this area has been left to state regulation..$^{13}$ In that guise, there is a considerable body of Illinois statutory and case law which bears directly and indirectly on the many situations which give rise to pre-trial delay.

1. Continuances associated with the obtaining of counsel. The criminal defendant in Illinois is entitled by statute to the advice of counsel before pleading to the charge..$^{14}$ If at the time of arraignment it appears that the defendant wants but has been unable to obtain counsel, the trial court is directed by statute to order a recess or to "continue the cause for a reasonable time" to enable the defendant to get a lawyer ${ }^{15}$ A continuance at arraignment is thus guaranteed as an incident of the right to counsel;16 similarly, but without express statutory sanction, continuances may be granted when the defendant changes counsel. However, if the defendant effectively waives his right to counsel, trial of the case without a continuance will not be grounds for reversal. Failure of the defendant to cooperate with counsel or to seek new counsel after the withdrawal of the old may operate as a waiver. ${ }^{17}$

12 In De Meerleer v. Michigan, 329 U.S. 663 (1947), a seventeen year old defendant in one day was arraigned, tried, convicted of first-degree murder, and sentenced to life imprisonment without being advised of his right to counsel or of the consequences of a plea of guilty. The Supreme Court reversed, per curiam, noting that "petitioner was deprived of rights essential to a fair hearing under the Federal Constitution." Id. at 665 .

13 The breadth of those limits may be gauged by People v. Shrum, 12 Ill. 2d 261, 146 N.E.2d 12 (1957). There the defendant, who appeared pro se, was arraigned, tried for murder, and sentenced to 199 years imprisonment all in one day. The mlinois Supreme Court upheld the conviction, distinguishing De Meerleer, supra note 12, on the ground that De Meerleer had not been advised of his right to counsel or of the consequences of his plea. "While we do not approve of the hurried procedure here employed, we cannot say as a matter of law that it operated to deprive the defendant of due process of law:" 146 N.E.2d at 14.

14 ILL. REv. StAT. ch. 38, \& 113-3(a) (1965).

15 Id.

10 See, e.g., People v. Stevens, 68 I11. App. 2d 265, 215 N.E.2d 147 (1966). But cf. People v. Culbert, 69 IIl. App. $2 d 162,215$ N.E.2d 470 (1966), where, in a proceeding to adjudicate defendant a sexually dangerous person, defendant did not knowingly waive his right to indictment by a grand jury. Held: "under certain factual situations" it may be necessary for the accused to have the advice of counsel to make this decision, and the proper course for the trial judge would have been to order a short continuance to allow accused to obtain and consult with counsel. 215 N.E.2d at 473.

17 See, e.g., People v. Solomon, 24 III. 2d 586, 182 N.E.2d 736, cert. denied, 371 U.S. 853 (1962). Defendant was arraigned on December 29, 1960, at which time the Public Defender was appointed without defendant's objection to represent him. On January 10, the day before the scheduled trial date, the Public Defender requested a continuance, stating that defendant had not cooperated with him and had insisted that his friends would get him counsel of his own choice. Held: not error to deny the continuance and proceed to trial; 
Where there have been several changes of counsel and continuances, reviewing courts sometimes say that a defendant cannot use his right to counsel solely to secure continuances and "thereby thwart the administration of justice."18

2. Delay associated with pre-trial motions. Illinois statutes authorize a variety of pre-trial motions which when made by the defendant entail some delay in getting the case to trial. These include motions to dismiss, ${ }^{19}$ motions for a bill of particulars ${ }^{20}$ or a list of witnesses, ${ }^{21}$ for a substitution of judges ${ }^{22}$ or a change of venue, ${ }^{23}$ for severance, ${ }^{24}$ and

defendant had not shown prejudice resulting from the denial of extra time. Moreover, as he had had two weeks to obtain counsel and had refused to cooperate with the Public Defender, he could not complain of counsel's lack of preparation. Accord, People v. Jackson, 28 Ill. 2d 37, 190 N.E.2d 823 (1963); People v. Robinson, 27 III. 2d 289, 189 N.E.2d 243 (1963); People v. Stokes, 18 Ill. 2d 371, 164 N.E.2d 26 (1960).

18 See, e.g., People v. Solomon, supra note 17, 24 Ill. 2d at 590. But cf. People v. Ritchie, 66 III. App. 2d 417, 213 N.E.2d 306 (1966), one of the few reversals for failure to allow time to procure counsel. When the case came up for trial six weeks after arraignment, the Public Defender requested a continuance on the ground that the defendant's family was trying to retain counsel for him. When the motion for a continuance was denied, the Public Defender withdrew, and the defendant appeared pro se at trial. Held: an abuse of discretion; defendant had been in custody the entire time and sincerely believed that private counsel was being obtained for him. His request for extra time did not reflect a lack of diligence and could not be viewed as an attempt to thwart the ends of justice.

19 A motion to dismiss must be in writing. ILL. REv. STAT. ch. 38, $\$ 114-1$ (1965). If it states facts not in the record, the state must file an answer and a hearing must be held. Motions to dismiss must be filed "within a reasonable time" after arraignment, presumably to prevent cases from being held up in later stages by challenges to the sufficiency of the indictment or other preliminary matters.

20 A motion for a bill of particulars, $i d$. $\$ 114-2$, must also be filed within "a reasonable time" after arraignment. Case law limiting the extent of discovery allowed through the bill of particulars, People v. Diekelmann, 367 Ill. 372, 11 N.E.2d 420 (1937), and making the granting of the motion discretionary with the trial court, People v. Tsukas, $406 \mathrm{III}$. 613, 94 N.E.2d 895 (1950), can be applied to curtail use of the motion as a delaying tactic.

21 The defendant may move to require the state to furnish a list of prosecution witnesses. ILl. REv. STAT. ch. 38, \$ 114-9 (1965). The state may then need time to compile the list, and defendant to investigate its contents. The primary purpose of the motion is plainly to assist the accused in preparing his defense, but it may also serve to reduce delay at later stages of the proceedings by preventing surprise at trial and costly duringtrial continuances. The prosecution is not, however, confined at trial to the list of witnesses whose names were on the list, if it appears that their names were not or could not reasonably have been known when the list was compiled. Id.

22 Two procedures for the substitution of judges are authorized by III. REv. STAT. ch. 38, § 114-5 (1965). Automatic substitution is allowed on the defendant's written motion within 10 days after the case has been placed on trial call. No hearing is involved; the case is simply assigned to another judge. The second procedure, a motion for substitution of judges for cause, is allowed at any time, but must be supported by affidavit and requires determination at a hearing. Thus, the statute encourages defendants to change judges early in the proceedings when the costs are minimal; later motions, made when the trial judge has presumably heard more of the case, are scrutinized more carefully and are presumably less frequent.

23 A motion for a change of place of trial, id. § 114-6, must be in writing and sup- 
motions to suppress confessions ${ }^{25}$ or illegally seized evidence. ${ }^{26}$ The amount of time consumed varies with statutory requirements that the motion be in writing, that the state be permitted to answer, or that a hearing be held. The granting of most pre-trial motions is in the discretion of the trial court, ensuring the court's ability to cut off delaying or spurious motions. The statutes, although silent as to the time to be expended on such motions, are designed to some extent to encourage them to be made as early as possible. Automatic substitution of judges, for example, is allowed if sought early, while a later motion requires a hearing at which cause must be shown. ${ }^{27}$ Occasional case law imposition of a timeliness requirement reflects a similar assumption that delay at earlier stages of the proceedings is less costly than later delay.

3. Continuances proper. Continuances may result from a request for additional time unrelated to pre-trial motions and the like. The statute lists several grounds which constitute an appropriate basis for such a request: that counsel has died, is ill, or is held to trial in another cause, or has been unable to prepare for these reasons; that a material witness is unavailable, provided that the prosecution will not stipulate to his testimony; that the defendant has been taken by surprise by an amendment of a bill of particulars; that defendant is unable to stand trial by reason of physical or mental illness; and that defendant has been prejudiced by publicity. ${ }^{28}$ This enumeration is not exclusive, as the trial court is permitted to order a continuance "whenever the interests of justice" require. When a motion for continuance is made

ported by an affidavit showing prejudice in the county where the trial is to take place. $A$ hearing is required.

24 Severance may be ordered at the trial court's discretion at the instance of court, state, or defendant. Id. § 114-8. The statute permits such motions to be made at any time; case law, however, imposes a timeliness requirement preventing convictions from being upset if the motion was delayed, particularly if it was made after the jury was sworn in. People v. Bindrin, 404 III. 532, 89 N.E.2d 530, cert. denied, 339 U.S. 939 (1950).

25 The statute authorizes both a motion to produce a confession, IrL. REv. STAr. ch. 38, § 114-10 (1965), and a motion to suppress a confession, id. § 114-11. If a motion to suppress states facts which if true would show involuntariness, the court must hold a hearing, at which the burden of going forward and of proof by a preponderance of the evidence is on the state. These motions, because they require a hearing with presentation of evidence by both sides, can consume considerable time. The safeguard against frivolous motions and unnecessary delay is the trial court's discretion in determining when the allegations of the motion are sufficient to merit a hearing.

26 A motion to suppress illegally seized evidence must state facts showing the unlawfulness of the search and seizure, and issues of fact must be determined at a hearing. Id. § 114-12. The motion must be made before trial unless the defendant was unaware of the grounds or did not have opportunity to make it.

27 Id. \& 114-5.

28 Id. § 114-4(b). 
later than thirty days after arraignment, the trial court may require an accompanying affidavit stating the facts on which the motion is based. The affidavit's major purpose is probably in connection with motions based on the absence of a material witness, ${ }^{29}$ since the willingness of the prosecution to stipulate to the anticipated testimony extinguishes the basis for the motion. It may also be that the affidavit was intended to be used selectively by trial courts as a means of cutting off dilatory motions.

Since the granting of continuances is by statute discretionary with the trial court, a conviction will not be reversed on appeal unless denial of extra time amounted to an abuse of discretion..$^{30}$ It is not enough that the motion was made on grounds which the statute deems appropriate. For example, although prejudicial publicity is given as a basis for a continuance, there appears to be no case in which a conviction was set aside for failure to grant a continuance because of publicity. ${ }^{31}$ The test seems rather to be based on the circumstances of the case as a whole, and several factors must usually combine to make out an abuse of discretion.32 A further control is the statute's declaration that

29 See, e.g., People v. Prochut, 27 Ill. 2d 298, 189 N.E.2d 290 (1963), in which counsel failed to file an affidavit requested by the trial court and there was already sufficient positive identification of the defendant to support a conviction without the missing material witness.

30 The rule as it is usually stated is: "The granting of a continuance is within the trial judge's discretion, and his decision will not be disturbed on review unless it appears that the refusal to grant additional time hindered the accused in adequately presenting his defense." People v. Hannah, 54 IIl. App. 2d 218, 222, 203 N.E.2d 764, 66 (1964).

31 Appellate courts have not been overly friendly to the request for a continuance based on pre-trial publicity, and tend to emphasize the alternative means open to the defense for combatting prejudice-the opportunity to seek a change of venue and to question prospective jurors on voir dire. See People v. Hagel, 32 IIl. 2d 413, 206 N.E.2d 699, cert. denied, 382 U.S. 942 (1965); People v. Wilson, 29 Il. 2d 82, 193 N.E.2d 449 (1963), cert. denied, 377 U.S. 955 (1964).

32 Special circumstances which have been pointed to as justifying delay include the indigence of the defendant, his having been in custody rather than out on bail and consequent inability to prepare his own defense, and the fact that multiple defendants were involved or that the case was complicated on the law or facts. In the absence of such circumstances, a reviewing court is likely simply to compute the number of days which elapsed between arraignment and trial and say that the period was sufficient for preparation of the case. See, e.g., People v. Sauber, 68 Ill. App. 2d 133, 214 N.E.2d 918 (1966).

Sufficient "special circumstances" were found in the famous Crump murder case, where counsel's motion for a continuance was supported by an affidavit alleging that since his appointment he had been continuously engaged in other cases and had not had time to prepare. On the day the motion was argued, the state submitted a list of 48 new witnesses. The trial judge's decision to order the case to trial twelve days later was held an abuse of discretion. People v. Crump, 5 III. 2d 251, 125 N.E.2d 615 (1955). See also People v. Kenzik, 9 IIl. 2d 204, 137 N.E.2d 270 (1956), in which court-assigned counsel claimed to be busy in other cases and had talked with his client only three times for 15-20 minutes. The state objected to a continuance on the ground that its sick, 77-year old witness from 
motions for continuances be considered "in light of the diligence of the movant." 33 If the case had already been continued, if the defendant failed to ask for more time, or if the need for delay was occasioned by the defendant himself, he may be foreclosed from contending on appeal that he had inadequate time to prepare. ${ }^{34}$ In addition to discretion and diligence, reversals are controlled by a case-law rule of prejudice; denial of the continuance must have adversely affected the outcome of the trial. This rule is sometimes applied stringently as if to require the defendant to establish that he would not have been convicted had he had more time.35

Although denial of a continuance is a frequent ground of appeal, reversals are infrequent. Reviewing courts seem to apply the rules of discretion, diligence, and prejudice stringently, perhaps from a belief that convictions ought not, absent unusual circumstances, be upset for technical reasons. Reversals may also be infrequent, however, because defendants usually have plenty of time to prepare their cases. If cases are so scheduled that considerable time elapses between arraignment and trial, and if courts are ordinarily liberal in granting continuances, occasional denial of extra time may be more likely to represent the cutting off of blatantly spurious delay rather than an abuse of discretion.

4. Delay occasioned by the state. The state's freedom to seek delay is limited by the defendant's constitutional right to speedy trial. That right is implemented in Illinois by the 120-day or Fourth Term statute, which requires that an incarcerated defendant be tried within 120 days of being taken into custody "unless delay is occasioned by the defendant, by a competence hearing, or by an interlocutory appeal." ${ }^{\text {"36 }} \mathrm{A}$ defendant who is released on bail may demand trial at any time and must be tried within 120 days of his demand unless the delay is occasioned by the defendant or by an interlocutory appeal.

Mississippi might not be available at a later date. Held: denial of continuance was an abuse of discretion; some latitude must be allowed in a capital case where attorney is appointed by the court.

33 See, e.g., People v. Walden, 21 Ill. 2d 164, 171 N.E.2d 650 (1961); People v. Stewart, 412 Ill. 106, 105 N.E.2d 72 (1952), cert. denied, 346 U.S. 916, 348 U.S. 919 (1953).

34 See, e.g., People v. Solomon, 24 Ill. $2 d$ 586, 182 N.E.2d 736, cert. denied, 371 U.S. 853 (1962); People v. Dery, 74 Ill. App. 2d 112, 219 N.E.2d 536 (1966); People v. House, 73 III. App. 2d 345, 219 N.E.2d 580 (1966). In Dery, defendant, who had escaped from prison before his trial, argued that his attorney had been unable to prepare by reason of his absence. Held: attorney's lack of preparation was not a ground for reversal when it was the consequence of the defendant's own conduct.

35 See, e.g., People v. Wilson, 29 Ill. 2d 82, 193 N.E.2d 449 (1963), cert. denied, 377 U.S. 995 (1964); People v. Barnes, 26 Ill. 2d 563, 188 N.E.2d 7 (1963); People v. Clark, 9 III. 2d 46, 137 N.E.2d 54 (1956), cert. denied, 352 U.S. 1002 (1957); People v. Turner, 60 III. App. 2d 388, 208 N.E. 2d 406 (1965).

36 IrL. REV. STAT. ch. 38, § 103-5(a) (1965). 
Within the limits of the 120-day rule, the state has some opportunity comparable to that of the defendant to delay trial of a case. These are not, of course, delays associated with pre-trial motions, other than those incident to the state's right to contest defense motions either by a written answer or at a hearing. The same statute which authorizes defense motions for continuances permits motions by the state. The enumerated grounds are only slightly narrower; a continuance may be sought where the prosecutor assigned to the case has died, is ill, or is held to trial in another cause (but not, as with defendant's motions, where he has been unable to prepare for these reasons); where a material witness is unavailable; and where pre-trial publicity has prejudiced the prosecution. The policy of the statute appears to put state and defendant on an equal footing: "This section shall be construed to the end that criminal cases are tried with due diligence consonant with the rights of the defendant and the State to a speedy, fair, and impartial trial."'37

In general, the legal system appears to treat continuances as a routine matter best left to the discretion of trial court judges. It may well be, given the variety of situations in which the interests of fair hearing may call for a continuance, that more precise statutory regulation is neither feasible nor desirable, and that flexibility at the trial court level is preferable to a statutory strait jacket. One consequence of this approach, however, is the virtual non-existence of appellate control over continuances. Application of the standards of abuse of discretion and prejudice means that reversals for failure to allow continuances are infrequent. At the other end of the spectrum, the discretionary framework leaves reviewing courts no means of restricting the overly lax use of continuances. Thus the legal system, while it imposes some lower limit on continuances, imposes no upper limit; to evaluate continuance control, we must look to the practices of trial judges.

\section{Continuances in the Courts}

The law on continuances is the very small tip of a very big iceberg. For the most part, the granting and denial of continuances goes on almost unaffected by the legal framework; the important rules which the system follows are rules of administrative practice rather than of law. A brief survey of the Cook County criminal court system and its daily operations is thus an essential part of the background for a study of continuances.

The Cook County criminal court system is composed, loosely speaking, of two tiers, the Criminal Division, ${ }^{38}$ which has jurisdiction over

37 Id. \& $114-4(\mathrm{~g})$.

38 The Criminal Division is one of seven specialized divisions of the County Department of the Circuit Court of Cook County. 
indicted felonies, ${ }^{39}$ and the Municipal Department, the courts of which hear misdemeanors and ordinance violations. The Municipal Department is divided geographically into six Districts, of which the First District comprises what was once the Municipal Court of Chicago. ${ }^{40}$ The First District is divided in turn into 37 branches, of which six have jurisdiction not only over misdemeanors and ordinance violations but also to conduct preliminary hearings in felony cases: these are Rackets Court, Women's Gourt, Boys' Courts North and South, Narcotics Court, and Felony Court. ${ }^{41}$ This study was directed toward the Criminal Division, which entertains felony cases on a county-wide basis, and toward the six Branches of the First District which try misdemeanor and ordinance violations committed in the city of Chicago and conduct preliminary hearings in felony cases. It does not encompass the other two Divisions (County and Juvenile) of the County Department which handle criminal or quasi-criminal matters, and it does not include either the misdemeanor courts of Cook County outside of Chicago or the "police courts" in Chicago which do not conduct preliminary hearings.

Defendants in Chicago who are charged with misdemeanors or ordinance violations are tried by the appropriate branch court, or, if a jury is demanded, by a special branch of the First District known as Jury and Non-Jury Court. ${ }^{42}$ If there is a felony charge as well, a hearing will be held to determine whether there is probable cause to justify holding the case over to the Cook County grand jury for indictment and fur-

$39 \mathrm{Or}$, if indictment by the grand jury is waived, when a bill of information has been filed. Proceedings in misdemeanor and ordinance violations are on a complaint.

40 The Cook County and Chicago courts were integrated and reorganized in 1964. The system in all its complexity is explored in Oaks \& Lehman, supra note 9, at 584, 593-98.

41 To the Rackets Court are referred gambling, extortion, concealed weapons, and fraud cases. Women's Court hears most cases involving women over the age of 18. Boys' Courts North and South get all cases involving either as offenders or victims males between the ages of 17 and 21, as well as cases of auto theft. Narcotics Court receives narcotics offenses and cases involving defendants who have a record of narcotics offenses. Felony Court handles most preliminary hearings not referred to one of the other specialized branches. In addition to holding preliminary hearings, these six courts also try misdemeanor and ordinance violations within their own subject matter or geographical area. Oaks \&: Lehman, supra note 9, at 596.

42 This branch was once called Jury Court. It has long been customary for defendants appearing in one of the other branches on a misdemeanor charge to request jury trial, have their case transferred to Jury Court, and then waive jury trial and submit to a bench trial. The jury demand was a well known device for gaining time, as well as for "forum shopping." There was also the chance that complainants in misdemeanor cases would not take the trouble of reappearing at another court. In any event the jury demand, transfer to Jury Court, and waiver of jury trial became so commonly recognized as a delaying device that the court was renamed "Jury and Non-Jury Court." Oaks \& Lehman, supra note 9, at 596. 
ther prosecution. If probable cause is not established, or if the felony charge is dropped in favor of a misdemeanor, the case will be concluded in the misdemeanor court. If the case is held over from the misdemeanor court for indictment by the Cook County grand jury or if, as sometimes happens, an indictment is returned "directly" without a preliminary hearing stage, ${ }^{43}$ the defendant will be arraigned by the presiding judge of the Criminal Division. At arraignment the defendant's plea is entered; sometimes a continuance is necessary to enable him to obtain counsel before pleading to the charge. The presiding judge also fixes bail, which supplants any bail set at the preliminary hearing. If the defendant pleads guilty at arraignment, the presiding judge may pronounce sentence, usually after a continuance; more commonly, the defendant pleads not guilty and the presiding judge assigns the case for trial before one of the 12 associate judges of the Criminal Division.

Although practices in the two types of courts are similar in many respects, procedures in the Criminal Division are somewhat more formal, and cases take longer, than in the misdemeanor courts which handle a greater volume of less serious cases. Defendants in felony cases generally have counsel. If they are indigent, the Public Defender will be assigned to the case or, if the defendant so requests, a three-man team of Bar Association lawyers may sometimes be appointed. Legal representation in the misdemeanor courts has long been more perfunctory.44 $\mathrm{Al}$ though defendants are free to retain counsel, most do not; if they are represented at all, it is by one of the two municipal defenders assigned to the several courts. In the misdemeanor courts there is very little if any preparation of cases before they are called; often the state's attorney reads the complaint for the first time as the bailiff reads the charges. Again, while no hard line can be drawn, it is in the indicted cases that the full panoply of pre-trial motions, discovery, and the like, are drawn into play.

43 The bypassing of the preliminary stage can occur in many situations, as for example, when it appears in the course of a grand jury investigation or other proceeding that a certain person was involved in an offense. The grand jury then returns an indictment, sending the case "directly" to the Criminal Division. Oaks \& Lehman, supra note 9, at 597.

44 For a description of the system as it existed at the time of this study, see Oaks \& Lehman, supra note 9, at 688-95. In 1966, the Public Defender's Office assumed responsibility for Felony, Narcotics, and Jury Court, leaving an expanded Municipal Defender's staff to handle the remaining Municipal Department branches. Since court-assigned counsel do not file appearances in the misdemeanor courts, there is no way of checking the regularity of representation. Nor, as Oaks and Lehman point out, does the appointment of counsel guarantee his presence at the hearing. Preparation usually consists of a few minutes' conversation with the defendant before an on-the-spot trial. Oaks \& Lehman, supra note 9, at 692-93. 
In both the Criminal Division and the misdemeanor courts, all cases scheduled to be heard on a given day are called for 10 A.M. Since court calls are not staggered, witnesses, defendants, and police officers must all be on hand early in the day regardless of when the case is actually called. Some judges make a practice of calling cases which are to be continued first, or of giving preference as a matter of professional courtesy to those in which retained lawyers are present. In general, however, those required to appear in a case have no way of knowing when it will be called. In the preliminary courts, witnesses come to court on every scheduled court date. In the Criminal Division, the system is somewhat more selective; witnesses are subpoenaed by the state's attorney or by the defense when it is anticipated that they will be needed. Witnesses are not subpoenaed, and do not attend, court appearances at which testimony is not taken, as, for example, the arraignment or the filing of discovery or other preliminary motions. Even when witnesses are subpoenaed, however, there is no guarantee that the case will go forward as scheduled; if it is continued, the witnesses will have come to court for nothing unless notified informally in advance of the continuance. Particularly in the crowded misdemeanor courts, the observer's impression is one of great haste and confusion; it is not surprising that witnesses sometimes do not realize that the case has been continued, or do not hear the date of the next court appearance.45 Commentators have criticized these features of the daily rat race in the criminal courts both for their inefficiency and for the burdens which they impose upon witnesses. For present purposes, it seems enough to note the contribution of these administrative facts of life to continuance costs.

Judges and attorneys in both sets of courts stress the informality with which motions for continuances are handled. Judges never require, as they are authorized by statute to do, that motions for continuances be accompanied by an affidavit. This procedure is ignored, they say, because it involves an extra continuance for preparation of the affidavit; moreover, since a judge is unlikely as a practical matter to challenge the truth of an attorney's sworn statement, the affidavit means little more than the attorney's word in court. Nor, in the vast majority of instances, do judges even require motions for continuances to be in writing. The making of pre-trial motions is noted briefly and becomes a matter of record. When motions for continuances are granted, however, a record of the reasons is not usually made, apart from the fact

45 For an earlier observer's impressions of unseemly haste, see Dash, Cracks in the Foundation of Criminal Justice, 46 ILL. L. REv. 385, 388-90 (1951); the point is reiterated by Oaks \&: Lehman, supra note 9 , at 730-33. 
of the continuance. If the continuance is denied, no record is made at all other than is saved in the transcript for appeal. The defense or state's attorney who wants a continuance can thus simply appear in court on the scheduled date and state that he is not ready for one reason or another. Objections, if any, will be settled in court. In indicted cases particularly, some attorneys consider it a matter of good manners to notify the opposing party a day or two in advance of their intention to seek a continuance. If the other party is willing, the attorney knows his motion will be unopposed. For his part, the other party is glad to have the information because he can then notify his witnesses that they do not need to go to court.

The procedural simplicity of the continuance machinery is matched by the informality with which the grounds for continuances are treated. The legal rules are pushed well into the background; one judge said that he has never looked at the statute. Rather than inquire closely into the reasons, many judges say that they apply a standard policy of granting one or two continuances to either party on request; "after that, they'd better have a good reason." Other judges are willing to permit as many "by agreement" continuances as the parties are willing to arrange; close scrutiny is called for, they contend, only when one side is losing its witnesses or otherwise objects to further delay. ${ }^{48}$

To say that the continuance process is treated informally or routinely is not, of course, to establish that unnecessary continuances are tolerated. For one thing, some of the informal mechanisms work to reduce continuance costs. The practice of notifying witnesses that they need not appear in court may save a great deal of time and energy, although it is difficult to estimate how regularly it is done. Judges report a number of devices aimed at reducing continuance costs. Some pay particular attention to defendants who are in jail unable to make bail, permitting only short continuances in such cases. In misdemeanor courts, judges may dismiss a case for want of prosecution when the complaining witness fails to appear rather than permit the state's attorney a continuance. One misdemeanor court judge saves witnesses from having to reappear in court in cases where the defendant's attorney fails to appear by permitting witnesses to testify as to physical evidence as long as no mention of the defendant is made. The informality of the con-

40 The President's Commission declares: "Responsibility for managing the court's calendar and for the orderly hearing of cases should lie primarily with the court, not with the parties. If courts are to exercise effective calendar control .... they must reject consent of the parties as a basis for granting adjournments. . . . The question of allowable delay must be thought of in terms of broader interests than the convenience or desires of the primary participants in the proceedings." TASK FORCE REPORT, supra note 2 , at 86 . 
tinuance mechanism may itself save costs, as judges and lawyers insist, by reducing to a minimum the time spent in getting continuances.

While the pressure of time undoubtedly tends to informality, it is harder to say that it also contributes to unnecessary continuances. Indeed, the pressure of time seems to cut both ways. Judges have too many cases on their daily court calls, and so must continue some or acquiesce in the parties' requests for continuances. On the other hand, judges want to "clear the docket" and to keep up with their share of the workload. Similarly, state's attorneys may in some instances need a continuance, but must keep abreast of their workload. They must keep an eye on the Fourth Term rule, although its impact can be avoided by consenting to "by agreement" continuances rather than making direct requests for more time. The State's Attorney's Office is also subject to the pressure of public opinion, and of its watchdog, the Illinois Crime Commission. The Public Defender's Office, which represents roughly half of the defendants in the Criminal Division, is undoubtedly overburdened; the Office has a policy, however, of getting through its load by requesting no more continuances than are necessary. Since the pressure of time may operate to reduce as well as increase the number of continuances, it is hard to say that this pressure, and the informality it engenders, necessarily contribute to continuance abuse.

Another factor which may operate to inflate the volume of continuances is the reluctance of some judges to risk reversals: "It's a guaranteed reversal to force a case to trial when the defendant is not ready." This fear seems unfounded, since there have been only a handful of reversals in recent years for denial of continuances. It may be, however, that what the judges are expressing is a newly-born sensitivity to recent developments in criminal procedure reforms; they are no longer willing to reject as frivolous or dilatory a defendant's request for change of counsel, a psychiatric examination, or the like. It is difficult for judges to discriminate between legitimate and marginal motions at a time when the bases for legitimate motions are expanding; judges may prefer to err on the side of leniency. Other judges, however, insist that they have no fear of reversal, and are strict with continuances because they want to clear their dockets. This discretionary framework plainly allows for considerable variation among judges in continuance policy; whether these variations are translated into significant differences in the number and length of continuances remains to be established.

A factor which may work toward the liberal use of continuances is a general lack of concern for continuance costs. While by no means universal, there is also a sense that continuances are ordinary aspects 
of everyday life, harmless as long as nobody objects. Judges may allow lawyers some latitude as a matter of professional courtesy. State's attorneys who are reluctant to ask for a continuance may have no objection to a defense or "by agreement" motion which tolls the Fourth Term rule. Defendants who want delay can thus take advantage of the system's lack of opposition.

It would appear, in summary, that there is a considerable discrepancy between the law on continuances and the practices of the Cook County criminal courts. The motion-by-motion evaluation which the law seems to contemplate is replaced in the courts with more or less automatic reflexes; in place of the defined statutory grounds are generalized concerns for how long the case has been on the docket and how the witnesses are faring. The informal continuance may not be a bad thing; indeed, it may even be that the statutory formulae were never supposed to regulate the administrative life of the trial courts but were rather intended as rules to be applied on appeal. The significant question would appear to be, rather, how effectively the informal mechanism works to control the level of continuances. Interviews with judges and attorneys have given us some indication that continuance control is loose, whether because of the pressure of time, judicial fear of reversal, or a general insensitivity to continuance costs. There have also been some suggestions that the system relies on informal mechanisms to reduce continuance costs. To learn how well it all works, we turn to our empirical investigation of continuances in the criminal courts.

\section{Data Analysis}

The statistics ${ }^{47}$ presented in detail in the concluding appendix may be summarized in the following correlations: the proportion of guilty dispositions decreases as the number of court appearances increases; ${ }^{48}$ retained attorney cases take longer than public defender cases; ${ }^{40}$ cases involving white defendants take longer than cases involving non-white defendants; ${ }^{50}$ the proportion of guilty dispositions of white defendants with retained counsel shows a disproportionate decline over time; ${ }^{51}$ bailed cases take longer than jailed cases; ${ }^{52}$ a lower proportion of con-

47 Part $I$ of the Appendix describes in some detail the methods used to gather the data and the time periods the data covers. The most important fact to note at this point is that the first appearance in the indicted cases is arraignment and the last is sentencing. In the preliminary hearing cases, the last appearance is either sentencing or a holding over to the grand jury.

48 See table 3.

49 See table 10 .

50 See table 27.

51 See table 14.

52 See table 24. 
tinuances have their reason explained for retained counsel than for the public defender; ${ }^{53}$ defendants with prior records take longer to try than defendants with no prior record. ${ }^{54}$

The statistics serve first of all to describe the continuance process in the Cook County criminal courts. The task of description is important, and demands extensive compilation of court records barely begun by this study. Apart from their rudimentary descriptive value, however, the sample data offer a starting point for analysis of the relationship between continuances and the characteristics of cases and defendants. Our analysis proceeded along two major lines. First, we asked whether the data reflect continuance abuse; that is, whether a significant portion of continuances represent delay which the legal system deems to be without social value. Second, we turned to the costs associated with continuances, to ask whether it can be established that the volume of continuances in the Cook County criminal courts results in lost convictions and in wasted witness, police, and court time.

\section{A. Continuance Abuse}

It is quite clear from the sample data that defendants with some characteristics take longer to come to trial than do defendants with other characteristics. Most prominently, defendants who have retained lawyers, who are white, who are released on bail before trial, and who do not have prior criminal records are likely to have more court appearances than defendants who are represented by the Public Defender, who are Negro, who are not released on bail, and who have prior criminal records. ${ }^{55}$

On its face, the profile of the continuance-prone defendant is consistent with the abuse hypothesis, since the more affluent, more sophisticated defendant is in a better position to abuse the system. By the same token, however, it is the more affluent and sophisticated defendant who is in the best position to exercise the legitimate options which the system affords. The problem in comparing the high-level and the low-level continuance groups is thus one of isolating factors which point unmistakably to abuse rather than to a picture which merely confirms common understanding that the rich get a different kind of justice than do the poor.

1. Why do cases handled by retained counsel take longer? Thirtyeight percent of the cases handled by retained lawyers require more than eight court appearances to come to final disposition; only nine

53 See table 21.

54 See table 23.

65 See tables 10, 27, 24, 23. 
percent of the Public Defender's cases take as long. ${ }^{56}$ The median length of retained lawyers' cases is 7.2 court appearances, ${ }^{57}$ two months longer than the Public Defender's median case, which requires 3.7 court appearances. ${ }^{58}$ This differential persists when the two populations are further dichotomized. Thus, cases of bailed clients with retained lawyers take longer than cases of bailed clients of the Public Defender.59 A similar differential persists when cases involving clients who are white, ${ }^{60}$ who are accused of multiple crimes, ${ }^{61}$ who are accused of more serious crimes, ${ }^{62}$ and so forth ${ }^{63}$ are compared, establishing that the presence of a retained lawyer is a factor associated with a longer case regardless of the type of client.

The discrepancy between the length of cases handled by retained lawyers and those handled by public defenders will prove most significant if it can be established that the only consistent difference between the two groups of clients is their ability to pay for legal representation. If it happened, for example, that defendants who were sure of conviction were able to decide to save themselves some money by not hiring a lawyer, then it could be argued that the relative dispatch of the Public Defender's cases is attributable to the obvious guilt of a large portion of his clients. The thoroughness of the "means test" applied by the courts in assigning counsel to the indigent is thus of some importance. If the "means test" is thorough, then the rich could not get public defender representation even if they wanted it, and the poor would be "locked in" to the public defender system by lack of funds in all cases. Under such conditions, the self-selection of guilty defendants into the Public Defender's Office could be discounted. We were assured by court observers, judges, and members of the Public Defender's staff that "free rides" do not occur often because the "means test," while informal, is rigorously applied by persons who are both experienced and sufficiently overworked to have an incentive to watch the caseload. It is also very possible that the image of the "charity lawyer" among the defendant population is not sufficiently attractive to make even a "free ride" appear to be a bargain; sentencing must still be dealt with in guilty-plea cases. We thus make the assumption -not altogether a comfortable one-that the only factor which dis-

56 See table 10.

57 See table 1, item 11 .

58 Id.

60 See table 15.

60 See table 13.

61 See table 17.

02 Id.

o3 See tables 19, 23, 9. 
tinguishes the Public Defender's population from that of the retained lawyer is money, a factor presumably unrelated to guilt or innocence, simplicity or complexity of case, or other variables which might account for legitimate, system-approved variations in the number of court appearances. This uncomfortable assumption is given some credence by the fact that the Public Defender's clients do not have prior records significantly more often than retained attorney clients; $17 \%$ of the Public Defender clients, $15 \%$ of the retained clients, and $16 \%$ generally have prior records. ${ }^{64}$

We then look for differences in the strategy or practices of retained lawyers which account for the greater time required to dispose of their cases. Two such considerations are professional and financial responsibility. Retained lawyers are responsible professionally as well as financially to their clients, while the Public Defender is paid by his organization and is professionally responsible to it as well as to his client. The Public Defender's Office has a policy, prompted both by the workload and by a desire to maintain high ethical standards, of discouraging unnecessary continuances; the individual defender is expected by his superior to be ready for trial when his cases are called and not to seek delay without a "good" reason. The retained lawyer, by contrast, is prompted both by a financial interest and perhaps by an undivided sense of obligation to do what his client wants, or at least what his client wants and can pay for. There may be other reasons apart from greater responsiveness to client pressure which impel delay on the part of the retained lawyer. Fee collection may motivate him while it does not motivate the Public Defender. The geographical distances between law offices and courts may cause delay on the part of the retained lawyer not demanded of the centralized operations of the Public Defender's Office. ${ }^{65}$ The picture of the Public Defender setting a standard of nonabuse while the private lawyer exploits his clients and the system should not be overdrawn. A less salutary construction might be explored which portrays the private lawyer working hard in the interests of each client while the Public Defender, his vigors sapped by bureaucracy, merely goes through the motions.

Perhaps the most convincing evidence that the high-level continuance cases of retained lawyers involve dilatory tactics rather than harder work is that $21 \%$ of the retained lawyer cases in which the client changes his plea from not guilty to guilty require more than nine court appearances. ${ }^{66}$ Only $6 \%$ of the Public Defender's cases where

64 See table 23.

65 The practice of the Public Defender's Office is to assign one of its lawyers to each judge, thereby largely eliminating the possibility of schedule conflict.

66 See table 9. 
the plea is changed to guilty require more than 8 appearances. ${ }^{67}$ It might well be argued that these defendants in both client populations are guilty, but that the retained lawyer prolongs the proceedings in his cases in the hope of weakening the prosecution's cases, subjecting it to public pressure, ${ }^{68}$ bargaining for a lesser charge, and the like, while the Public Defender does not. Inasmuch as the likelihood of conviction on a reduced charge almost doubles in the longest cases, the defendant's expectations seem to be rewarded. ${ }^{69}$

A second factor suggestive of abuse on the part of retained lawyers is their relatively strong insistence on the presence of witnesses. Fiftyfive percent of court appearances in cases involving retained lawyers were scheduled "with subpoenas," by contrast with $45 \%$ in the Public Defender's cases. ${ }^{70}$ Taking into account the greater length of retained lawyer's cases as well as the larger portion of appearances with subpoenas, it develops that witnesses are summoned twice as often in private lawyer cases as in those of the Public Defender. ${ }^{71}$ The frequency with which witnesses actually appear may be debatable, since lawyers contend that they notify witnesses who will not be needed a day or a few hours in advance of the scheduled appearance. It nonetheless appears that retained lawyers are relatively generous with the time of witnesses, and it could be argued that this generosity reflects, if not a conscious desire to "wear out" witnesses, at least a generalized feeling that having the witnesses summoned several times will not do any harm. Public defenders might be thought less vulnerable, albeit not immune, to the charge of scheduling repeated appearances with the hope of a dismissal for want of prosecution.

A final indicator of abuse by retained counsel is the disproportionate frequency of unexplained continuances in their cases. Clerks apparently record reasons for continuances only when the reason is important in some way to the administration of the case. Thus, over $80 \%$ of the

67 Id.

68 The Illinois Crime Commission keeps track of the number of long-pending cases, with a view to measuring the efficiency of the State's Attorney's Office.

69 See table 12.

70 Interval data for appearances with subpoenas looks like this:

\begin{tabular}{lrrrr}
\hline & \multicolumn{4}{c}{ Number of Appearances } \\
Type Lawyer & $1-3$ & $4-6$ & $7-9$ & $10+$ \\
\hline Retained & 108 & 67 & 20 & 18 \\
Public Defender & 146 & 25 & 3 & 2 \\
Other & 51 & 29 & 18 & 10 \\
Total & 305 & 121 & 41 & 30 \\
\hline
\end{tabular}

71 See table 1, item 12. 
recorded reasons for continuances are related to formal motions such as those to vacate a bond forfeiture warrant, to obtain discovery, to substitute judges, and the like. The remaining $20 \%$ of explained continuances are traceable to the absence of the defendant, which is important to the bailiff because a bond forfeiture or other warrant may be needed. There are, however, a very large number of unexplained continuances, particularly in retained lawyer cases: some explanation is visible for only $30 \%$ of the retained lawyers' continuances, while a reason is recorded in $56 \%$ of the Public Defender's requests. ${ }^{72}$ These "unexplained" continuances are doubtless sought for a variety of reasons: scheduling problems, ${ }^{73}$ lack of time to prepare, failure of the defendant to cooperate, and "professional reasons" (which probably means fee collection). Some of them are probably attributable to the absence of witnesses (defendants are recorded as absent on 275 occasions while there are only 12 such indications for witnesses, who in practice face no sanction for failures to appear). The absence of a witness seems inevitably to result in scheduling of another appearance on the motion of the party who called the witness without any formal note made on the records. In any event, it is clear that private lawyers ask for more continuances not related to the administration of the case than do public defenders. That fact alone suggests, if not deliberate delay, at least an absence of dispatch on the part of retained lawyers in handling their cases.

There is probably no way to demonstrate, at least within the confines of this study, the extent to which the greater length of retained lawyers' cases is attributable to harder work on their part rather than to such nonlegitimate or nonproductive factors as deliberate delay, scheduling conflicts, and fee collection. Commentators have concluded that retained lawyers, at least where poor clients are involved, actually do less investigative work than does the Public Defender, particularly now that the Public Defender's Office has been given a special staff and appropriations for this purpose. ${ }^{74}$ The sample data shed little light on this question. The relative frequency of motions made by retained lawyers, an average of 1.9 per case by contrast with 0.8 for the Public Defender, ${ }^{75}$ is hardly conclusive, since the disparity may reflect dilatory as well as soundly-based motions. A more suggestive clue is that judges and state's attorneys ask for approximately the same number of continuances

72 See table 21.

73 Several judges commented that they felt some attorneys were not above deliberately creating a schedule conflict in order to get a continuance in the case that was worst off.

74 See Oaks \& Lehman, "The Criminal Process of Cook County and the Indigent Defendant", 1966 IrL. L.F. 584, 717.

75 See table 1, item 13. 
regardless of whether a retained lawyer or the Public Defender is in the case; $;^{76}$ they at least do not seem to find much difference in the complexity of the cases handled by the two types of lawyers.

To summarize, it may be said that the sample data indicate that a substantial portion of the greater number of continuances obtained by retained lawyers represents the tactical use of delay, scheduling inefficiencies, fee collection, and other causes not directly related to the administration of the case and not legitimate within the framework of the legal system. The contention that they do more work on their cases has not been disproved, but nothing has appeared to substantiate it. However cautious one might wish to be about setting up the Public Defender as a model of good practice, it does appear that he is less guilty than his private colleagues of continuance abuse.

2. Race as a factor in obtaining continuances. The cases of white defendants involve more court appearances than the cases of nonwhites, ${ }^{77}$ and this differential holds when whites and non-whites are matched by type of crime, ${ }^{78}$ seriousness of crime, ${ }^{79}$ type of lawyer, ${ }^{80}$ bail status, ${ }^{81}$ and plea history. ${ }^{82}$ This disparity cannot be attributed to the relative poverty of non-whites, and the consequent inability to command a tenacious defense. Some racial differences exist between the public defender and jailed defendant populations on the one hand, and the general defendant population on the other. Non-whites comprise almost the same portion of the total defendant population $(58 \%)$ as of the Public Defender's clients $(62 \%) ; 83$ they comprise $66 \%$ of the defendants not able to make bail, as against $58 \%$ of the total defendant population for which both bail and race information were available..$^{84}$ But these differences do not explain why $32 \%$ of white defendants' cases, but only $20 \%$ of non-white defendants' cases, last for more than 8 court appearances. ${ }^{85}$ Among both the Public Defender's clients, and the jailed defendants, where difference in resources are presumably not significant, whites get more continuances. ${ }^{86}$ The relationship between race and continuances was somewhat surprising to the authors of this study, who had assumed that it would be more or less camouflaged in other categorizations rather than visible on the surface. The

76 See table 22.

77 See, e.g., table 27.

78 See table 29.

79 See table 31.

80 See table 13.

81 See table 26.

82 See table 8.

83 See table 13.

84 See table 26.

85 See table 27.

86 See tables 13, 26. 
sample data points to the conclusion, however, that lawyers-and probably judges, states' attorneys, and the system as a whole-pay less attention to Negro defendants and take less time with their cases. It may also be supposed that Negroes are less sophisticated than even white defendants of similar economic status, and perhaps more nearly apathetic and resigned to what they consider the inevitable outcome of their encounter with the criminal process. ${ }^{87}$

3. Other factors. The cases of defendants who obtain release on bail take longer than those of defendants who do not make bail, regardless of race ${ }^{88}$ or type of lawyer. ${ }^{89}$ This is doubtless true in part because lawyers and judges expedite the cases of defendants held in jail, in part because the County Jail is an unpleasant place, and in part because at the time of this writing, no sentence credit was given for pre-trial detention. While it is likely that the greater length of the on-bail defendants' cases reflects their greater wealth as a group, and consequently their greater attractiveness and ability to pay higher fees, it is impossible to separate the effect of these factors from the effect of the system's efforts to give scheduling preferences to non-bailed defendants.

Finally, it is interesting to note that defendants with prior criminal records are disposed of more quickly than defendants for whom no indication of a prior record was available..$^{00}$ The differential persists when the comparison is made within a class represented by the same type of lawyer. ${ }^{91}$ While the data affords an inadequate basis for conclusions, the relationship is probably associated with the reluctance of judges to set low bonds for defendants with prior records, and is thus an aspect of the relationship between the length of cases of bail and non-bail defendants.

4. Conclusions. It would appear that the court system devotes more time to the cases of defendants with retained lawyers and to those who are white, and that there is no justification for this disparity in terms of greater complexity or difficulty of these cases. Moreover, the extra effort devoted to these favored groups of defendants seems to reflect to a considerable extent their pursuit of delay for its own sake, and the

87 See table 8. Although we have not chosen to concentrate on it, non-whites are also found guilty much more frequently than white defendants, regardless of the manner in which the sample is bifurcated. See, e.g., tables 14, 28, 30. Even the fact that non-whites receive more charge reductions may reflect discrimination in the form of less adequate screening by the State's Attorney and the grand jury. See table 32. However, it does not appear that non-whites suffer greatly in the hands of the sentencing process. See tables 33, 34. But see Note 97 infra.

88 See table 26.

89 See table 15.

90 See table 23.

91 Id. 
efforts of private lawyers to collect fees and to cope with their scheduling and other difficulties.

\section{B. Costs Associated with Continuances}

It is perfectly clear that continuances involve costs to the criminal justice system. Court congestion rises as case length increases; delay may lead to the commission of more crimes by bailed defendants; continuances give rise to costs under any of the commonly accepted theories of penal sanction..$^{22}$ In an attempt to shed some light on two of the more commonly mentioned and least well documented costs of continuances, the following discussion concentrates on whether delay causes an unjustifiable loss of convictions and an unnecessary increase in witness effort over time.

1. Lost convictions as a cost of continuances. The use of the terminology "lost convictions" as a cost is in a sense misleading. In actuality, the costs of any disproportionate differences in conviction rates over time may be better expressed as "unjustifiable convictions." However, the impressions upon the operators of a system are often as important as the actual operation of a system. Throughout the analysis which follows it is important to remember that if it appears that one group of persons is getting a "better deal" than another group, the administrators of the system are more likely to conceive of the result as a "lost convictions" cost.

The most salient relationship between the number of court appearances and convictions is that, with few exceptions, ${ }^{93}$ the conviction rate decreases as the case length increases. ${ }^{94}$ For the whole sample, the per-

92 See discussion pp. 259-63 supra.

93 The important exceptions to this pattern are the cases with more than thirteen appearances in both the table tabulating bail status against conviction rate, see table 25 , and the table tabulating race against conviction rate, see table 28. Both of these are explained by reference to the "not available" column in the table; there is no race or bail status information about a number of defendants who were acquitted in this longest group of cases. If this information were available, these defendants would appear in the two main columns so that the downward trend in the conviction rate would remain unbroken. Somewhat more puzzling is the experience of the non-white defendant with retained counsel, whose conviction rate actually increases over time. See table 14. This may also be a reflection of a high number of acquitted defendants for whom race is not known, but in this instance it is not possible to check this possibility. Another explanation lies in the fact that $1 / 3$ of the cases in this column include drug charges, which involve non-whites $90 \%$ of the time and which result in convictions $95 \%$ of the time. See tables 29,20 . In any event, since this result stands alone and has no ready explanation, it seems most likely that it represents some particularly obscure form of discrimination which should not be taken to compromise the general observation that conviction rates are consistently lower as the cases become longer. There are also discrepancies because of small sample size. See, e.g., the Public Defender's non-white defendant in table 14.

94 See tables $3,4,11,14,16,18,20,25,28,36,40$. It also seems to be true that the proportion of guilty dispositions involving conviction on a reduced charge increases over 
centage found guilty drops from $92 \%$ in cases taking between one and four court appearances to $48 \%$ in cases taking 17 or more court appearances. ${ }^{95}$ The most striking example of this trend is the white defendant with retained counsel, whose conviction rate drops from $86 \%$ in cases lasting less than 5 appearances to $45 \%$ in cases taking more than 12 appearances. ${ }^{96}$

Several hypotheses may be made in an attempt to relate the drop in conviction rate over time to an unnecessary loss of convictions. At one extreme, it could be said that the granting of any continuance is a sufficient condition for increasing the likelihood of obtaining a non-guilty disposition. Therefore any "abuse" of continuances could be said to cause unnecessary loss of convictions. At the other extreme, one could hypothesize that continuances have no influence on the dispositions, and that lengthy cases simply involve types of problems most likely to lead to a non-guilty disposition. Finally, it could be said that continuances are a necessary, but not sufficient, condition for a disproportionate loss of convictions. ${ }^{97}$

If it is true that any continuance heightens the chance of obtaining a non-guilty disposition, it would follow that the conviction rate for retained attorney cases, for example, would decrease at a faster rate over time than would the rate for public defender cases. This would be true because retained attorney cases involve more continuances than do public defender cases. Similarly, the conviction rate for white defendants or bailed defendants would decrease at a faster rate than would the rate for non-white or jailed defendants. However, the data does not demonstrate any disproportionate decline in conviction rates over time.

The easiest way to tabulate decline in conviction rates is to compute increase in acquittal rates. Thus, retained attorneys obtain about three times the number of non-guilty dispositions as does the Public Defender in cases involving from one to four court appearances. ${ }^{98}$ However, this ratio (3:1) does not increase over time; in fact it decreases. ${ }^{99}$ Similar re-

time. See table 12. This is not surprising. Presumably the same pressures which lead to non-guilty dispositions also lead to reduction of charges.

95 See table 3.

96 See table 14.

97 One other theory is certainly possible. It may be that the drop in conviction rate results from an informal system of giving credit for pre-trial time in jail. The quick answer lies in the fact that most of the defendants in long cases are out on bail. See table 24. It is also important to note that the drop in conviction rate is as rapid for those on bail as for those defendants in jail. See table 25. Such mercy as the system expresses seems to appear in the sentencing process, where the longer cases of jailed defendants have a higher percentage of defendants sentenced to probation, at the expense of combination prison and probation sentences. See table 6.

98 See table 11.

99 This data also indicates that the overall difference in conviction rates between re- 
sults appear when conviction rates are tabulated by race and bail status. ${ }^{100}$ Thus, it cannot be said that continuances themselves are a sufficient condition to cause loss of convictions.

Nor does it appear that the short cases simply involve obviously guilty defendants while the lengthy cases involve "hard" problems most likely to lead to a non-guilty disposition. If this theory is approached frontally, the obvious problem of isolating the "hard" cases from the "easy" cases arises. It could be argued that if the easy cases involve the "obviously guilty" defendants, then the hard cases involve "not guilty plea" cases. While it is true that the conviction rate for not guilty plea cases does decline over time, ${ }^{101}$ this is not particularly conclusive evidence that the general decline in conviction rate over time is not due to the concentration of hard issues in longer cases; there are certainly easy as well as hard not guilty plea cases. Although the sample size prevented detailed breakdowns by crime, it is doubtful that such an analysis would add very much; just as there are hard and easy not guilty plea cases, there are also hard and easy larceny cases.

Despite the inability to obtain explicit "proof" that the decline in conviction rate over time is not simply due to a concentration of hard issues in long cases, there are clear indications that case difficulty is not a necessary condition for conviction rate decline. The most startling statistics of this study, presented in Table 14, indicate that the conviction rate for white defendants who have retained counsel declines at a faster pace than does the conviction rate for non-white defendants who have retained counsel. It is difficult to contend that lengthy non-white retained attorney cases involve less difficult problems than do lengthy white retained attorney cases. One's imagination must be expanded considerably to argue that "borderline" arrests and prosecutions are more likely to occur among the white population than among the non-white. The apparent result is that the overall tendency for the conviction rate to decrease over time cannot be caused simply by the distribution of

tained and public defender cases cannot be caused simply by the presence of continuance abuse among retained attorneys. Some other factor must be at work. It is probable that public defenders simply are harder pressed. As a matter of course the Public Defender must plead a large number of people guilty to keep his head above water. This theory seems borne out by the fact that a much larger proportion of plea changes (from not guilty to guilty) occurs in the earlier cases of the Public Defender than of the retained attorneys. See table 9. This is apparently not due to a disproportionate use of plea bargaining by the Public Defender. See table 12.

100 Tables 25 and 28 are not perfectly conclusive on the point. As noted previously, see note 93 supra, the tables are skewed because of the high proportion of unknown data for cases lasting for 13 or more appearances. However, if we play the untidy game of redistributing the unknown non-guilty dispositions in the same proportion as the known data, it does not appear that there is a disproportionate drop in conviction rates for white or bailed defendants.

101 See table 4. 
most of the harder cases among longer proceedings, or the easier cases among the shorter proceedings.

We are left with the possibility that lengthy proceedings are a necessary but not a sufficient condition for unnecessary loss of convictions. Such a possibility seems adequately supported by the disproportionate decline over time in the conviction rate of white defendants using retained counsel as compared to the decline for other defendants. ${ }^{102}$ It is also possible that successfully obtaining one's release on bail would add significantly to the decline in the conviction rate of white defendants with retained counsel. ${ }^{103}$ Thus the data suggests the strong possibility that there is a conviction cost over time for certain types of defendants.

We close this section in the same vein as we opened it. The statistics do not tell us whether the conviction cost should be expressed in terms of loss of convictions of white defendants with retained counsel, or in terms of unjustifiable gain in conviction rates of other defendants. However, it was noted previously when discussing the influence of race upon the granting of continuances ${ }^{104}$ that lawyers, and probably other judicial officials, seem to pay less attention to non-white than to white defendants. Making a further inference, it may be possible to say either that continuances produce lost convictions when the case is "taken seriously" by the operators of the judicial system or that unnecessary convictions occur over time when the case is "taken lightly." At any rate, the operators of the system of criminal justice are probably correct in their feeling that there is a conviction cost involved in certain types of extensive litigation.

2. Witness time as a cost of continuances. On first impression, one would assume that the longer the case, the more often a witness would be required to appear in court. This impression is fortified by the data, although there is a slight tendency for the number of appearances set with subpoenas to rise less rapidly than the total number of appearances. ${ }^{105}$

Many of our respondents stated, however, that witnesses are notified not to appear when they are not needed, even if a subpoena has been issued. We were not able to measure the effectiveness of this notification system, and it therefore can be argued that the longer case's increased number of subpoenas is offset by a greater number of notifications. Despite these statements, it seems unlikely that the informal notification

102 See table 14.

103 See tables 16, 25. Such a result would not be surprising, for economic status may determine bail status as well as attorney selection.

104 See notes 85-87 and accompanying text supra.

105 See table 5. 
system is wholly effective; lawyers apparently do try to wear out witnesses. ${ }^{106}$ Furthermore, there is the inherent difficulty of contacting witnesses on short notice to tell them they need not come to court.

\section{Continuances in Preliminary Hearing Courts}

In the preliminary hearing courts, the only facts about a case which are consistently recorded are the charge, the number of court appearances, the race and sex of the defendant, and the final disposition. In addition, appearances were filed by private counsel in $20 \%$ of the 573 cases, ${ }^{107}$ al though there is no way of knowing if this figure represents all of the appearances by retained lawyers.

Despite the rudimentary nature of the data, it is possible to conclude that the major trends evident in indicted cases are also present in the lower courts. Specifically, the conviction rate drops sharply as the length of the case increases, ${ }^{108}$ cases with retained lawyers take longer than the sample as a whole, ${ }^{109}$ and white defendants take longer and are less often found guilty than non-whites. ${ }^{110}$

As in the indicted cases, these trends seem to be strong evidence that some defendants receive an unjustifiably large number of continuances, and that convictions in certain types of cases are unnecessarily lost over time. Furthermore, the differences between the lower courts and the Criminal Court do not seem to lessen abuse in the lower courts. To the contrary, the less serious nature of the charges, the lack of subpoenas, and the informality of the proceedings make it more likely that witnesses would fail to return, and that counsel would therefore seek delay.

However, whatever abuse exists may be counteracted by the considerably shorter average length of the preliminary hearing cases. ${ }^{111} \mathrm{It}_{\mathrm{t}}$ is also possible that a number of the acquittals in the longer cases reflect the greater emphasis on conciliation in preliminary hearing courts, particularly in instances where the charges are brought by a private party rather than by the police. The most striking example of this conciliation role appears in cases where the wife files assault charges against her husband. If the husband is found guilty on the first court appearance, which is usually possible, the wife may shortly return to court asking the judge for her husband's release. Another typical conciliation situation involves theft among erstwhile friends, often, for some reason, of a television set. In these cases the common practice is to grant several

100 See notes 70-71 and accompanying text supra.

107 See table 38.

108 See table 36.

109 See table 38.

110 See tables $39,40$.

111 Compare table 2 with table 35. 
continuances to allow the victim to "cool off" and the perpetrator to make restitution; if there is a "cool" restitution the case is dismissed with stern warnings. In some juvenile court cases, continuances apparently are used to keep a boy in jail without giving him a record by dismissing the case only after setting a high bond and continuing the case for thirty days. Whatever one's view of the merit of these practices, they reduce the strength of the evidence of continuance abuse apparently displayed by the data.

\section{Proposals for Reform}

Some continuances are clearly necessary; others are clearly abusive. Perhaps the ends of the spectrum are best illustrated by delay for an incompetency commitment on the one hand, and delay to harass witnesses on the other. In between lie the "gray area" continuances, such as delays to obtain payment of legal fees. While the authors of this study look with some disfavor upon the "fee" continuance as one not directly concerned with the fair adjudication of guilt or innocence, it is not really the purpose of this section to analyze the pros and cons of such delays. Rather we wish to provide a means by which the judicial system and future commentators may more intelligently analyze borderline continuances; weighing benefits and costs of certain types of continuances cannot be accomplished with the data obtained for this study.

Similarly, our purpose here is not to answer the ethical problem of whether an attorney has a duty to take maximum advantage of the laxity of the continuance system. It is clear that conflicts of interest exist: if a public defender must abuse the system, he finds himself in conflict with the best interests of his employer; if a private attorney does not abuse the system, he may not be pursuing the best interests of his client. Our goal is simply to narrow the scope within which the ethical problems may be said to operate, while providing a means of making the issues visible to the bench and bar.

These limitations on our purposes still leave much room for reform. Clearly abusive continuances must be reduced; witnesses must not be brought to court unless they are needed. The modest recommendations which follow attempt to deal with these clear abuses while making the borderline continuance and ethical problems visible and therefore subject to intelligent investigation and discussion.

1. Reduction of continuances. Any effort to reduce continuances must confront the difficulty that lawyers will always be able to support a continuance request with an apparently legitimate reason. If judges began to refuse continuances based, let us say, on the lack of payment by clients, counsel could obtain a continuance by saying his client had 
not cooperated or that he was still seeking a key witness, or he could make a dilatory motion.

However, two goals remain quite plausible. First, some action should be taken to make it somewhat more difficult to obtain an unjustifiable continuance. Second, an attempt should be made to curb the significant continuance offenders. Despite the fact that attorneys may be able to disguise their reasons for asking for delay, it seems reasonable that the bailiffs should record the proffered reasons for every continuance granted, along with the name of the attorney requesting it. This device would, at a minimum, force attorneys to articulate legitimate reasons and judges to listen to and evaluate them. It may even have the beneficial effect of causing the parties to make use of the statutory criteria for granting continuances.

Furthermore, recordation of reasons would permit constant survey of the continuance situation by the State's Attorney's Office, the Clerk's Office, the Chicago Crime Commission, or some other body. Attorneys requesting large numbers of continuances, especially if they offered similar reasons for a large portion of their delays, could be cautioned or penalized by the bar. Note carefuly that the reform offered is not to discontinue granting continuances when certain suspect attorneys ask for them. The proper approach is to discipline the attorney rather than to risk prejudicing the defendants of certain attorneys. Such an attempt to curb significant offenders may in turn cause attorneys to pause before requesting an illegitimate continuance by offering a legitimate reason. Only time would tell whether such a deterrent effect could be established.

This reform is also especially important if we are ever properly to evaluate the borderline continuance and ethical problems. Only if later investigators are able to obtain a relatively true picture of the causes and costs of continuances can the judicial system hope to reach legitimate conclusions about "gray area" continuances and the "duty to abuse."

2. Reduction of wasted witness time. Reducing the time spent in court by witnesses could be accomplished by two expedients. First, it would be advisable to formalize the system of notifying witnesses when they have received a subpoena but are not actually needed in court. This could readily be accomplished by having each witness fill out a form indicating where he can be reached, both at home and at work; these sheets could be filed in a central location, either with the State's Attorney's Office or the Office of the Chief Clerk of the Criminal Court. This accomplished, attorneys would be required to notify this central office of intent to request a continuance by the evening before the court 
date, whereupon the witnesses could be contacted. A trial of this system would be able to establish whether sanctions would be necessary to enforce the notification requirement. If sanctions are found to be needed, the lawyer could be charged $\$ 5.00$, or some other amount, for each witness who unnecessarily appeared in court, this sum to be returned to the witness as partial compensation for his time.

Second, as other commentators have suggested, ${ }^{112}$ the court calls should be divided into at least a morning and an afternoon session. This would reduce the waiting time for witnesses who presently appear at the single 10:00 A.M. call, but wait until the afternoon before their cases are called. Such a reform would also reduce the time wasted by attorneys waiting for cases. ${ }^{113}$

112 See Oaks \& Lehman, supra note 74 , at 734.

113 The Chicago Police Department currently allows officers who appear in court a stipulated three hours of time credit for each appearance. Some officers in court said that this was too low a figure, and that this results in reluctance of an officer to make an arrest before his days off. 


\section{APPENDIX}

\section{The Data: Setting and Methods}

The basic data for this study of continuances in the criminal courts of Cook County is derived from a sample, obtained in the summer of 1966, of court records from cases in the Criminal Division (indicted felonies) and the six branches of the Municipal Department which try misdemeanors and ordinance violations and serve as preliminary hearing courts in felony cases. The choice of court records as a source of data was in part compelled by necessity, since court records are more accessible and more nearly complete than any records kept by the Police Department or the State's Attorney's Office. Court records also seemed the most logical source of information in light of the purposes of the study, which is concerned with the effect of continuances on the administration of justice in the courts. Since continuances "happen" in the courts, it appeared that the information needed for the study would most likely be available in court records.

The decision to use a sample, rather than to compile information on the workings of the court system as a whole, was influenced by two primary considerations. First, reliable statistics on the operation of the Cook County courts are sadly lacking and the difficulties of putting them together from the case records would have been beyond the capabilities of this project. Second, the aim of the study was not only to describe the operations of the system but also to study the use of continuances in some detail: to isolate patterns and to relate the use of continuances to particular factors which might account for variations. For this purpose, a sample procedure appeared both appropriate and necessary.

The object of the sampling was to enable us to study the court appearance histories of a large group of cases. To this end, we drew as the sample all cases in which the first court appearance took place during a certain period of time chosen arbitrarily (April-May, 1965). The selection of a period of time as the criterion for inclusion in the sample ensured the randomness of the sample, except insofar as the length of time which cases are pending is subject to seasonal variation. By choosing cases which began at roughly the same time rather than throughout the year, we effectively neutralized the effect of seasonal variation. At the same time, however, we did not eliminate variations which might be due to changes in the law, in court rules, in judges, and the like. The reason for choosing the point of first appearance rather than final disposition or some other state of the case was to make sure that all cases could be followed through on an equal footing; since we wanted to 
determine whether continuances cause cases to "get lost," we wanted to follow cases forward, rather than backward, in time. Since we wanted to have roughly the same number of Criminal Division (indicted felony) as Municipal Department cases, and since the volume of cases heard in the latter courts is greater than in the former, a longer period of time was needed from which to select Criminal Division cases. The sample thus consists of all cases in the six branches of the Municipal Department in which the first appearance took place during the month of April, 1965, and all cases in the Criminal Division in which indictments were returned to the Criminal Division during the months of April and May, 1965. Since the first court appearance in Criminal Division cases takes place at arraignment, that event has been designated the "date of first appearance" for the purpose of this study.

Rather than treat Criminal Division and Municipal Department cases on the same footing, as would have been done in a study of the court system as a whole, we collected an approximately equal sample from each set of courts and proceeded to study them separately. Thus, our "sample" consists effectively of two samples: one of indicted felony cases, and the other of misdemeanors, ordinance violations, and preliminary hearings in felony cases. There are several reasons for treating the two kinds of courts separately. First, it was expected that, because the Criminal Division cases are more serious, proceedings there would take longer than in the preliminary courts; a realistic picture of both courts could thus be obtained only by separating the cases. Second, there are differences in practice and procedure between the two types of courts which render the case data less than comparable: witnesses are subpoened in the Criminal Division but not in the municipal courts; the Public Defender files an appearance in the Criminal Division but not in the preliminary courts, and the like. Finally, it was hoped that by studying the two types of courts independently, we would be able to draw conclusions and make recommendations for change appropriate for each setting.

The information from the court records which was transcribed onto form sheets and later key-punched onto IBM cards for data processing fell into two broad categories: information with regard to the circumstances of each case, and information concerning the court appearance history of each case. The information available under each category may be summarized as follows:

\section{A. Data Concerning the Circumstances of the Case}

1. Presence and number of co-defendants. Where defendants were charged or indicted together, the court records contained one file for the case as a whole. We attempted to sort out the information in such files and to transcribe data about the defendants as individuals in both single and multiple defendant cases. Thus, we may for some purposes 
analyze the data in terms of the numbers and characteristics of individual defendants; for other purposes, we may break the data down in terms of cases and describe the progress of cases, rather than individuals, through the court system.

2. Age, race, and sex of defendant(s).

3. Date of arrest (preliminary cases only).

4. Bail history. Whether bail was set, made, and forfeited.

5. Defendant's previous criminal record. This information was not generally available. The weaknesses in the data cast doubt upon any findings about the relation between continuances and prior record.

6. Charges. Initial charge(s), charge(s) on which the case was disposed, and intervening charge reductions.

7. Final disposition. Whether guilty, not guilty, nolle prosse, SOL (stricken from record without leave to reinstate), nonsuit, DWP (dismissed for want of prosecution), discharge, and, in preliminary cases, held to grand jury for indictment.

8. Sentence.

9. Plea history. Whether plea, if any, of guilty, not guilty, or change in plea.

10. Whether other charges pending in other courts.

11. Counsel history. Whether and at what stage of proceedings counsel entered; whether counsel retained or assigned. In the Municipal Court branches, retained attorneys file appearances but the Public Defender does not; thus we have no information in the Municipal Court cases where there was no retained attorney as to whether the defendant was without counsel or was represented by the Public Defender's Office. In Criminal Division cases, we do not know whether the defendant was represented by counsel prior to arraignment; we can, however, trace the post-arraignment counsel history.

12. Jury history. Whether defendant demanded and subsequently received a jury trial.

13. Number of police and private witnesses.

\section{B. Data Concerning Court Appearance History}

This information was taken from the "minute sheet" in the folder of each case. The "minute sheet" is a running memorandum of orders entered in each case in which the judge or his bailiff notes the action taken at each appearance, and the date of the next one. The minute sheet furnished the following data:

1. Date of each appearance. From this we calculated the length of time between appearances from the first appearance (Municipal Court cases) or arraignment (felony indictment cases) to final disposition, which we defined to be the date on which charges were disposed of or, if sentencing was delayed, the date of sentencing.

2. Number of appearances. We omitted from the study data on pro- 
ceedings which followed final disposition; thus, we did not keep track of motions for rehearing, appeal, or other post-conviction proceedings.

3. Whether witness subpoened for each appearance in felony cases. Subpoenas are not used in Municipal Court cases.

4. On whose motion continuance to next appearance made. Motions by defendant, state, by agreement, or order of court are the four types made.

5. The judge before whom each appearance was made.

6. The reason. The "reason" consists of whatever indication the minute sheet contains as the reason for the delay, the business to be done at this or the next court appearance, and the like. These include absence of defendant, motions to suppress or for discovery, bond forfeitures, and a multitude of others. Some reason is entered in the minute sheet for about half the court appearances: interpreting what was going on in the other half is a major function of the study. The minute sheets do not furnish data on the denial of motions for continuances with any regularity. 
II. TABLES

TABLE 1

SUMTMARY INFORMATION

1. Total Number of Defendants: 524

2. Total Number of Cases: 376

3. Median Age of Defendants: 28

4. Distribution of Defendants by Race and Sex

$\begin{array}{ll}\text { White: } 206 & \text { Male: } 485 \\ \text { Non-white: } 285 & \text { Female: } 37 \\ \text { Not available: } 33 & \text { Not available: } 2\end{array}$

5. Bail Status

Out on bail: 242

Not out on bail: 152

Bail not set: 23

No information: 107

6. Number of Defendants with Multiple Charges: 240

7. Number of Convictions on Reduced Charges: 69

8. Use of Juries

Jury demanded and subsequently waived: 7

Jury trial: 22

No jury demanded: 495

9. Median Number of Witnesses

Private witnesses: 2.2

Police witnesses: $\mathbf{3 . 3}$

Total: $\mathbf{5 . 5}$

10. Median Number of Days from Arraignment to Final Disposition: 81

11. Median Number of Court Appearances: $\mathbf{5 . 8}$

Retained Counsel Cases: 7.2

Public Defender Cases: 3.7

12. Median Number of Court Appearances with Subpoenas

Retained counsel cases: 3.9

Public Defender cases: 1.9

Total cases: 2.9

13. Median Number of Motions for Continuances

By defendant: 1.4

Retained counsel: 1.9

Public Defender: 0.8

By the court: 2.2

By the State: 0.6

By agreement: 1.0

Not available: 0.6

14. Number of Motions to Suppress Evidence: $\mathbf{5 2}$ (10 granted)

15. Median Length of Continuances: 16.2 days

16. Number of Cases Still Pending

Total: 22

Retained counsel: 17

Public defender: I

Other: 4 
TABLE 2

Court Appearance $\times$ Length in Days*

\begin{tabular}{|c|c|c|c|c|c|c|c|c|c|c|c|}
\hline $\begin{array}{c}\text { Court } \\
\text { Appearances }\end{array}$ & $\begin{array}{l}0-39 \\
\text { Days }\end{array}$ & $\begin{array}{l}40- \\
79\end{array}$ & $\begin{array}{l}80- \\
119\end{array}$ & $\begin{array}{l}120- \\
159\end{array}$ & $\begin{array}{c}160- \\
199\end{array}$ & $\begin{array}{l}200- \\
249\end{array}$ & $\begin{array}{l}250- \\
299\end{array}$ & $\begin{array}{c}300- \\
399\end{array}$ & $\begin{array}{l}400- \\
499\end{array}$ & $500+$ & $\begin{array}{l}\text { Total } \\
\text { Cases }\end{array}$ \\
\hline $1-4$ & 150 & 51 & 9 & 4 & & & & & & & 214 \\
\hline $5-8$ & 11 & 45 & 37 & 43 & 9 & 9 & 4 & 1 & & & 159 \\
\hline 9-12 & & 1 & 4 & 17 & 15 & 18 & 6 & 10 & 3 & 1 & 75 \\
\hline $13-16$ & & & & & 4 & 4 & 9 & 4 & 3 & 4 & 28 \\
\hline $17+$ & & & & & & & & 25 & 17 & 2 & 44 \\
\hline
\end{tabular}

* Median Days Pending $=81$.

TABLE 3

$\%$ Guilty $\times$ Court Appearances*

\begin{tabular}{|c|c|}
\hline $\begin{array}{c}\text { Court } \\
\text { Appearances }\end{array}$ & $\begin{array}{c}\% \\
\text { Guilty }\end{array}$ \\
\hline $1-4$ & $\begin{array}{c}92 \% \\
181 / 197\end{array}$ \\
\hline $5-8$ & $\begin{array}{c}76 \% \\
109 / 143\end{array}$ \\
\hline $9-12$ & $\begin{array}{c}69 \% \\
49 / 62\end{array}$ \\
\hline $13-16$ & $\begin{array}{l}63 \% \\
12 / 19\end{array}$ \\
\hline $17+$ & $\begin{array}{c}48 \% \\
14 / 29\end{array}$ \\
\hline Total & $\begin{array}{c}80 \% \\
359 / 450\end{array}$ \\
\hline
\end{tabular}

* All indicted case tables reporting the conviction rate are based on the sum of defendants found guilty or not guilty or nolle prossed. This method excludes pending cases, cases in which the defendant jumped bond, and, because of a coding error, 14 cases in which an SOL was entered for reasons other than the defendant's deliberate absence.

TABLE 4

Court Appearances $\times \%$ Guilty, for Those Defendants Pleading Not Guilt

\begin{tabular}{ccc} 
Court & $\%$ \\
Appearances & Guilty \\
\hline \multirow{2}{*}{$5-4$} & $41 \%$ \\
& $7 / 17$ \\
& $9-12$ & $35 \%$ \\
& $13+$ & $12 / 34$ \\
& $24 \%$ \\
& Total & $4 / 17$ \\
& $27 \%$ \\
\end{tabular}


TABLE 5

Court Appearances $\times$ Median Number of Appearances with Subpoenas

\begin{tabular}{cc}
\hline Court & No. of \\
Appearances & Subpoenas \\
\hline $1-4$ & 1.7 \\
$5-8$ & 3.2 \\
$9-12$ & 6.1 \\
$13-16$ & 6.8 \\
$17+$ & 10.1 \\
Total & 2.9 \\
\hline
\end{tabular}

TABLE 6

Type Sentence $X$ Court Appearances

\begin{tabular}{ccccc}
\hline $\begin{array}{c}\text { Court } \\
\text { Appearances }\end{array}$ & Probation & $\begin{array}{c}\text { Prison }+ \\
\text { Probation }\end{array}$ & Prison & Total \\
\hline \multirow{2}{*}{$1-4$} & $23 \%$ & $22 \%$ & $55 \%$ & $100 \%$ \\
& 42 & 40 & 99 & 181 \\
$5-8$ & $19 \%$ & $20 \%$ & $61 \%$ & $100 \%$ \\
& 20 & 21 & 64 & 105 \\
$9+$ & $33 \%$ & $13 \%$ & $54 \%$ & $100 \%$ \\
& 22 & 9 & 36 & 67 \\
Total & $24 \%$ & $20 \%$ & $56 \%$ & $100 \%$ \\
& 84 & 70 & 199 & 353 \\
\hline
\end{tabular}

TABLE 7

Plea History $\times$ Court Appearances

\begin{tabular}{cccc}
\hline $\begin{array}{c}\text { Court } \\
\text { Appearances }\end{array}$ & Not Guilty & Changed to Guilty & Not Available \\
\hline \multirow{2}{*}{$1-4$} & $22 \%$ & $52 \%$ & $27 \%$ \\
& 26 & 169 & 22 \\
$5-8$ & $34 \%$ & $30 \%$ & $29 \%$ \\
& 40 & 96 & 24 \\
$9-12$ & $21 \%$ & $11 \%$ & $17 \%$ \\
& 25 & 36 & 14 \\
$13+$ & $23 \%$ & $7 \%$ & $27 \%$ \\
& 27 & 23 & 22 \\
Total & $100 \%$ & $100 \%$ & $100 \%$ \\
& 118 & 324 & 82 \\
\hline
\end{tabular}


TABLE 8

Race $\times$ Plea History $\times$ Court Appearanctes

\begin{tabular}{|c|c|c|c|c|c|c|}
\hline \multirow{2}{*}{$\begin{array}{c}\text { Court } \\
\text { Appearances }\end{array}$} & \multicolumn{2}{|c|}{ Not Guilty } & \multicolumn{2}{|c|}{ Change to Guilty } & \multicolumn{2}{|c|}{ Not Available } \\
\hline & White & Non-White & White & Non-White & White & Non-White \\
\hline $1-4$ & $\begin{array}{l}19 \% \\
11\end{array}$ & $\begin{array}{l}24 \% \\
11\end{array}$ & $\begin{array}{l}46 \% \\
53\end{array}$ & $\begin{array}{l}56 \% \\
116\end{array}$ & $\begin{array}{c}24 \% \\
8\end{array}$ & $\begin{array}{l}39 \% \\
13\end{array}$ \\
\hline $5-8$ & $\begin{array}{l}37 \% \\
21\end{array}$ & $\begin{array}{l}39 \% \\
18\end{array}$ & $\begin{array}{l}30 \% \\
35\end{array}$ & $\begin{array}{l}29 \% \\
60\end{array}$ & $\begin{array}{l}36 \% \\
12\end{array}$ & $\begin{array}{l}33 \% \\
11\end{array}$ \\
\hline $9+$ & $\begin{array}{l}44 \% \\
25\end{array}$ & $\begin{array}{l}37 \% \\
17\end{array}$ & $\begin{array}{l}24 \% \\
28\end{array}$ & $\begin{array}{l}15 \% \\
30\end{array}$ & $\begin{array}{l}39 \% \\
13\end{array}$ & $\begin{array}{c}27 \% \\
9\end{array}$ \\
\hline Total & $\begin{array}{c}100 \% \\
57\end{array}$ & $\begin{array}{c}100 \% \\
46\end{array}$ & $\begin{array}{l}100 \% \\
116\end{array}$ & $\begin{array}{l}100 \% \\
206\end{array}$ & $\begin{array}{c}100 \% \\
33\end{array}$ & $\begin{array}{c}100 \% \\
33\end{array}$ \\
\hline
\end{tabular}

TABLE 9

Type Counsel $\times$ Plea History $\times$ Court Appearances

\begin{tabular}{|c|c|c|c|c|}
\hline \multirow{2}{*}{$\begin{array}{c}\text { Court } \\
\text { Appearances }\end{array}$} & \multicolumn{2}{|c|}{ Not Guilty } & \multicolumn{2}{|c|}{ Change to Guilty } \\
\hline & Retained & Pub. Def. & Retained & Pub. Def. \\
\hline $1-4$ & $\begin{array}{l}22 \% \\
15\end{array}$ & $\begin{array}{c}30 \% \\
7\end{array}$ & $\begin{array}{c}45 \% \\
49\end{array}$ & $\begin{array}{l}74 \% \\
105\end{array}$ \\
\hline $5-8$ & $\begin{array}{c}22 \% \\
15\end{array}$ & $\begin{array}{c}61 \% \\
14\end{array}$ & $\begin{array}{c}35 \% \\
38\end{array}$ & $\begin{array}{c}20 \% \\
29\end{array}$ \\
\hline $9+$ & $\begin{array}{l}55 \% \\
37\end{array}$ & $\begin{array}{l}9 \% \\
2\end{array}$ & $\begin{array}{c}21 \% \\
23\end{array}$ & $\begin{array}{c}6 \% \\
8\end{array}$ \\
\hline Total & $\begin{array}{c}100 \% \\
67\end{array}$ & $\begin{array}{c}100 \% \\
23\end{array}$ & $\begin{array}{c}100 \% \\
110\end{array}$ & $\begin{array}{c}100 \% \\
142\end{array}$ \\
\hline
\end{tabular}

TABLE 10

TyPE LAWYER $X$ COURT APPEARANCes

\begin{tabular}{ccccc}
\hline $\begin{array}{c}\text { Court } \\
\text { Appearances }\end{array}$ & Retained & $\begin{array}{c}\text { Public } \\
\text { Defender }\end{array}$ & Other & Total \\
\hline $1-4$ & $32 \%$ & $65 \%$ & $21 \%$ & $41 \%$ \\
& 71 & 121 & 25 & 217 \\
$5-8$ & $30 \%$ & $26 \%$ & $39 \%$ & $31 \%$ \\
& 65 & 49 & 46 & 160 \\
$9-12$ & $20 \%$ & $5 \%$ & $19 \%$ & $14 \%$ \\
& 43 & 9 & 23 & 75 \\
$13+$ & $18 \%$ & $4 \%$ & $20 \%$ & $14 \%$ \\
& 40 & 8 & 24 & 72 \\
Total & $100 \%$ & $100 \%$ & $100 \%$ & $100 \%$ \\
& 219 & 187 & 118 & 524 \\
\hline
\end{tabular}


TABLE 11

Type Counser $\times \%$ Guilty $\times$ Court Appearances

\begin{tabular}{|c|c|c|c|c|}
\hline $\begin{array}{c}\text { Court } \\
\text { Appearances }\end{array}$ & Retained & Pub. Def. & Other & Total \\
\hline $1-4$ & $\begin{array}{c}86 \% \\
55 / 64\end{array}$ & $\begin{array}{c}95 \% \\
109 / 115\end{array}$ & $\begin{array}{c}94 \% \\
17 / 18\end{array}$ & $\begin{array}{c}92 \% \\
181 / 197\end{array}$ \\
\hline $5-8$ & $\begin{array}{l}72 \% \\
41 / 57\end{array}$ & $\begin{array}{l}72 \% \\
31 / 43\end{array}$ & $\begin{array}{l}86 \% \\
37 / 43\end{array}$ & $\begin{array}{c}76 \% \\
109 / 143\end{array}$ \\
\hline $9-12$ & $\begin{array}{c}61 \% \\
22 / 36\end{array}$ & $62 \%$ & $81 \%$ & $\begin{array}{c}69 \% \\
43 / 62\end{array}$ \\
\hline $13+$ & $\begin{array}{l}40 \% \\
10 / 25\end{array}$ & $8 / 13$ & $29 / 36$ & $\begin{array}{l}54 \% \\
26 / 48\end{array}$ \\
\hline Total & $\begin{array}{c}70 \% \\
128 / 182\end{array}$ & $\begin{array}{c}87 \% \\
148 / 171\end{array}$ & $\begin{array}{l}86 \% \\
83 / 97\end{array}$ & $\begin{array}{c}80 \% \\
359 / 450\end{array}$ \\
\hline
\end{tabular}

TABLE 12

Type Counsel $\times \%$ of Gullty Defendants Convicted on Reduced Charges $\times$ Court Appearances

\begin{tabular}{cccccc}
\hline $\begin{array}{c}\text { Court } \\
\text { Appearances }\end{array}$ & Retained & $\begin{array}{c}\text { Public } \\
\text { Defender }\end{array}$ & Other & Total & \\
\hline \multirow{2}{*}{$1-4$} & $18 \%$ & $15 \%$ & $0 \%$ & $14 \%$ & $1-4$ \\
& $10 / 55$ & $16 / 109$ & $0 / 17$ & $26 / 181$ & \\
$5-8$ & $27 \%$ & $16 \%$ & $14 \%$ & $19 \%$ & $5-8$ \\
& $11 / 41$ & $5 / 31$ & $5 / 37$ & $21 / 109$ & \\
\multirow{3}{*}{$9+$} & $25 \%$ & $38 \%$ & $14 \%$ & $16 \%$ & $9-12$ \\
\multirow{2}{*}{ Total } & $8 / 32$ & $3 / 8$ & $4 / 29$ & $7 / 43$ & \\
& $23 \%$ & $16 \%$ & $11 \%$ & $31 \%$ & $13+$ \\
& $29 / 128$ & $24 / 148$ & $9 / 83$ & $8 / 26$ & \\
& & & & $17 \%$ & Total \\
& & & & $62 / 359$ & \\
\hline
\end{tabular}

TABLE 13

Type Counsel $\times$ Rage $\times$ Court Appearanges

\begin{tabular}{|c|c|c|c|c|c|c|c|c|c|}
\hline \multirow{2}{*}{$\begin{array}{l}\text { Court } \\
\text { Appear- } \\
\text { ances }\end{array}$} & \multicolumn{3}{|c|}{ Retained Lawyers } & \multicolumn{3}{|c|}{ Public Defender } & \multicolumn{3}{|c|}{ Other Lawyers } \\
\hline & White & $\begin{array}{l}\text { Non- } \\
\text { White }\end{array}$ & $\begin{array}{c}\text { Not } \\
\text { Avail. }\end{array}$ & White & $\begin{array}{l}\text { Non- } \\
\text { White }\end{array}$ & $\begin{array}{c}\text { Not } \\
\text { Avail. }\end{array}$ & White & $\begin{array}{l}\text { Non- } \\
\text { White }\end{array}$ & $\begin{array}{l}\text { Not } \\
\text { Avail. }\end{array}$ \\
\hline $1-4$ & $\begin{array}{l}24 \% \\
22\end{array}$ & $\begin{array}{l}45 \% \\
45\end{array}$ & $\begin{array}{c}15 \% \\
4\end{array}$ & $\begin{array}{l}59 \% \\
41\end{array}$ & $\begin{array}{l}71 \% \\
79\end{array}$ & $\begin{array}{c}17 \% \\
1\end{array}$ & $\begin{array}{c}20 \% \\
9\end{array}$ & $\begin{array}{l}22 \% \\
16\end{array}$ & $\begin{array}{l}0 \% \\
0\end{array}$ \\
\hline $5-8$ & $\begin{array}{l}34 \% \\
32\end{array}$ & $\begin{array}{l}31 \% \\
31\end{array}$ & $\begin{array}{l}8 \% \\
2\end{array}$ & $\begin{array}{l}30 \% \\
21\end{array}$ & $\begin{array}{l}24 \% \\
27\end{array}$ & $\begin{array}{c}17 \% \\
1\end{array}$ & $\begin{array}{l}34 \% \\
15\end{array}$ & $\begin{array}{l}42 \% \\
31\end{array}$ & $\begin{array}{l}0 \% \\
0\end{array}$ \\
\hline $9+$ & $\begin{array}{l}42 \% \\
39\end{array}$ & $\begin{array}{l}24 \% \\
24\end{array}$ & $\begin{array}{c}77 \% \\
20\end{array}$ & $\begin{array}{c}10 \% \\
7\end{array}$ & $\begin{array}{l}5 \% \\
6\end{array}$ & $\begin{array}{c}67 \% \\
4\end{array}$ & $\begin{array}{l}45 \% \\
20\end{array}$ & $\begin{array}{l}36 \% \\
26\end{array}$ & $\begin{array}{c}100 \% \\
1\end{array}$ \\
\hline Total & $\begin{array}{c}100 \% \\
93\end{array}$ & $\begin{array}{l}100 \% \\
100\end{array}$ & $\begin{array}{c}100 \% \\
26\end{array}$ & $\begin{array}{c}100 \% \\
69\end{array}$ & $\begin{array}{l}100 \% \\
112\end{array}$ & $\begin{array}{c}100 \% \\
6\end{array}$ & $\begin{array}{c}100 \% \\
44\end{array}$ & $\begin{array}{c}100 \% \\
73\end{array}$ & $\begin{array}{c}100 \% \\
1\end{array}$ \\
\hline
\end{tabular}


TABLE 14

Type Counser $\times$ Race $\times \%$ Gullty $\times$ Court Appearances

\begin{tabular}{|c|c|c|c|c|c|c|}
\hline \multirow[b]{2}{*}{$\begin{array}{c}\text { Court } \\
\text { Appearances }\end{array}$} & \multicolumn{2}{|c|}{ Retained } & \multicolumn{2}{|c|}{ Public Defender } & \multicolumn{2}{|c|}{ Other } \\
\hline & White & $\begin{array}{l}\text { Non- } \\
\text { White }\end{array}$ & White & $\begin{array}{l}\text { Non- } \\
\text { White }\end{array}$ & White & $\begin{array}{l}\text { Non- } \\
\text { White }\end{array}$ \\
\hline $1-4$ & $\begin{array}{r}86 \% \\
18 / 21\end{array}$ & $\begin{array}{l}85 \% \\
35 / 41\end{array}$ & $\begin{array}{l}87 \% \\
33 / 38\end{array}$ & $\begin{array}{l}100 \% \\
76 / 76\end{array}$ & $\begin{array}{r}100 \% \\
6 / 6\end{array}$ & $\begin{array}{c}92 \% \\
11 / 12\end{array}$ \\
\hline $5-8$ & $\begin{array}{l}50 \% \\
14 / 28\end{array}$ & $\begin{array}{l}93 \% \\
26 / 28\end{array}$ & $\begin{array}{l}80 \% \\
16 / 20\end{array}$ & $\begin{array}{r}64 \% \\
14 / 22\end{array}$ & $\begin{array}{l}80 \% \\
12 / 15\end{array}$ & $\begin{array}{l}89 \% \\
25 / 28\end{array}$ \\
\hline $9+$ & $\begin{array}{c}45 \% \\
13 / 29\end{array}$ & $\begin{array}{l}86 \% \\
18 / 21\end{array}$ & $\begin{array}{l}71 \% \\
5 / 7\end{array}$ & $\begin{array}{l}100 \% \\
3 / 3\end{array}$ & $\begin{array}{l}75 \% \\
12 / 16\end{array}$ & $\begin{array}{c}84 \% \\
16 / 19\end{array}$ \\
\hline Total & $\begin{array}{c}58 \% \\
45 / 78\end{array}$ & $\begin{array}{c}88 \% \\
79 / 90\end{array}$ & $\begin{array}{l}83 \% \\
54 / 65\end{array}$ & $\begin{array}{c}92 \% \\
93 / 101\end{array}$ & $\begin{array}{c}81 \% \\
30 / 37\end{array}$ & $\begin{array}{l}88 \% \\
52 / 59\end{array}$ \\
\hline
\end{tabular}

TABLE 15

Bail Status $\times$ Type Counsel $\times$ Court Appearances

\begin{tabular}{|c|c|c|c|c|c|c|}
\hline \multirow{2}{*}{$\begin{array}{c}\text { Court } \\
\text { Appearances }\end{array}$} & \multicolumn{2}{|c|}{ Retained } & \multicolumn{2}{|c|}{ Public Defender } & \multicolumn{2}{|c|}{ Other } \\
\hline & Bailed & Jailed & Bailed & $\overline{\text { Jailed }}$ & Bailed & Jailed \\
\hline $1-4$ & $\begin{array}{l}31 \% \\
44\end{array}$ & $\begin{array}{l}49 \% \\
17\end{array}$ & $\begin{array}{l}56 \% \\
25\end{array}$ & $\begin{array}{l}69 \% \\
49\end{array}$ & $\begin{array}{c}17 \% \\
9\end{array}$ & $\begin{array}{c}13 \% \\
4\end{array}$ \\
\hline $5-8$ & $\begin{array}{l}27 \% \\
39\end{array}$ & $\begin{array}{l}37 \% \\
13\end{array}$ & $\begin{array}{l}27 \% \\
12\end{array}$ & $\begin{array}{l}28 \% \\
20\end{array}$ & $\begin{array}{l}35 \% \\
19\end{array}$ & $\begin{array}{l}51 \% \\
16\end{array}$ \\
\hline $9-12$ & $\begin{array}{l}24 \% \\
35\end{array}$ & $14 \%$ & $18 \%$ & $3 \%$ & $\begin{array}{l}22 \% \\
12\end{array}$ & $\begin{array}{c}19 \% \\
6\end{array}$ \\
\hline $13+$ & $\begin{array}{l}17 \% \\
25\end{array}$ & 5 & 8 & 2 & $\begin{array}{l}26 \% \\
14\end{array}$ & $\begin{array}{c}16 \% \\
5\end{array}$ \\
\hline Total & $\begin{array}{l}100 \% \\
143\end{array}$ & $\begin{array}{c}100 \% \\
35\end{array}$ & $\begin{array}{c}100 \% \\
45\end{array}$ & $\begin{array}{c}100 \% \\
71\end{array}$ & $\begin{array}{c}100 \% \\
54\end{array}$ & $\begin{array}{c}100 \% \\
31\end{array}$ \\
\hline
\end{tabular}

TABLE 16

BaIl Status $\times$ Type Counsel $\times \%$ GuILTY $\times$ Court appearances

\begin{tabular}{|c|c|c|c|c|c|c|}
\hline \multirow{2}{*}{$\begin{array}{c}\text { Court } \\
\text { Appearances }\end{array}$} & \multicolumn{2}{|c|}{ Retained } & \multicolumn{2}{|c|}{ Public Defender } & \multicolumn{2}{|c|}{ Other } \\
\hline & Bailed & Jailed & Bailed & Jailed & Bailed & Jailed \\
\hline $1-4$ & $\begin{array}{r}82 \% \\
32 / 39\end{array}$ & $\begin{array}{c}88 \% \\
15 / 17\end{array}$ & $\begin{array}{l}88 \% \\
22 / 25\end{array}$ & $\begin{array}{l}96 \% \\
45 / 47\end{array}$ & $\begin{array}{c}100 \% \\
9 / 9\end{array}$ & $\begin{array}{l}67 \% \\
2 / 3\end{array}$ \\
\hline $5-8$ & $\begin{array}{c}68 \% \\
23 / 34\end{array}$ & $73 \%$ & $67 \%$ & $76 \%$ & $\begin{array}{r}78 \% \\
14 / 18\end{array}$ & $\begin{array}{l}100 \% \\
18 / 18\end{array}$ \\
\hline $9+$ & $\begin{array}{c}62 \% \\
26 / 32\end{array}$ & $16 / 22$ & $12 / 18$ & $19 / 25$ & $\begin{array}{r}86 \% \\
19 / 22\end{array}$ & $\begin{array}{l}75 \% \\
9 / 12\end{array}$ \\
\hline Total & $\begin{array}{c}70 \% \\
81 / 105\end{array}$ & $\begin{array}{l}79 \% \\
31 / 39\end{array}$ & $\begin{array}{l}79 \% \\
34 / 43\end{array}$ & $\begin{array}{l}89 \% \\
64 / 72\end{array}$ & $\begin{array}{r}86 \% \\
42 / 49\end{array}$ & $\begin{array}{c}88 \% \\
29 / 33\end{array}$ \\
\hline
\end{tabular}




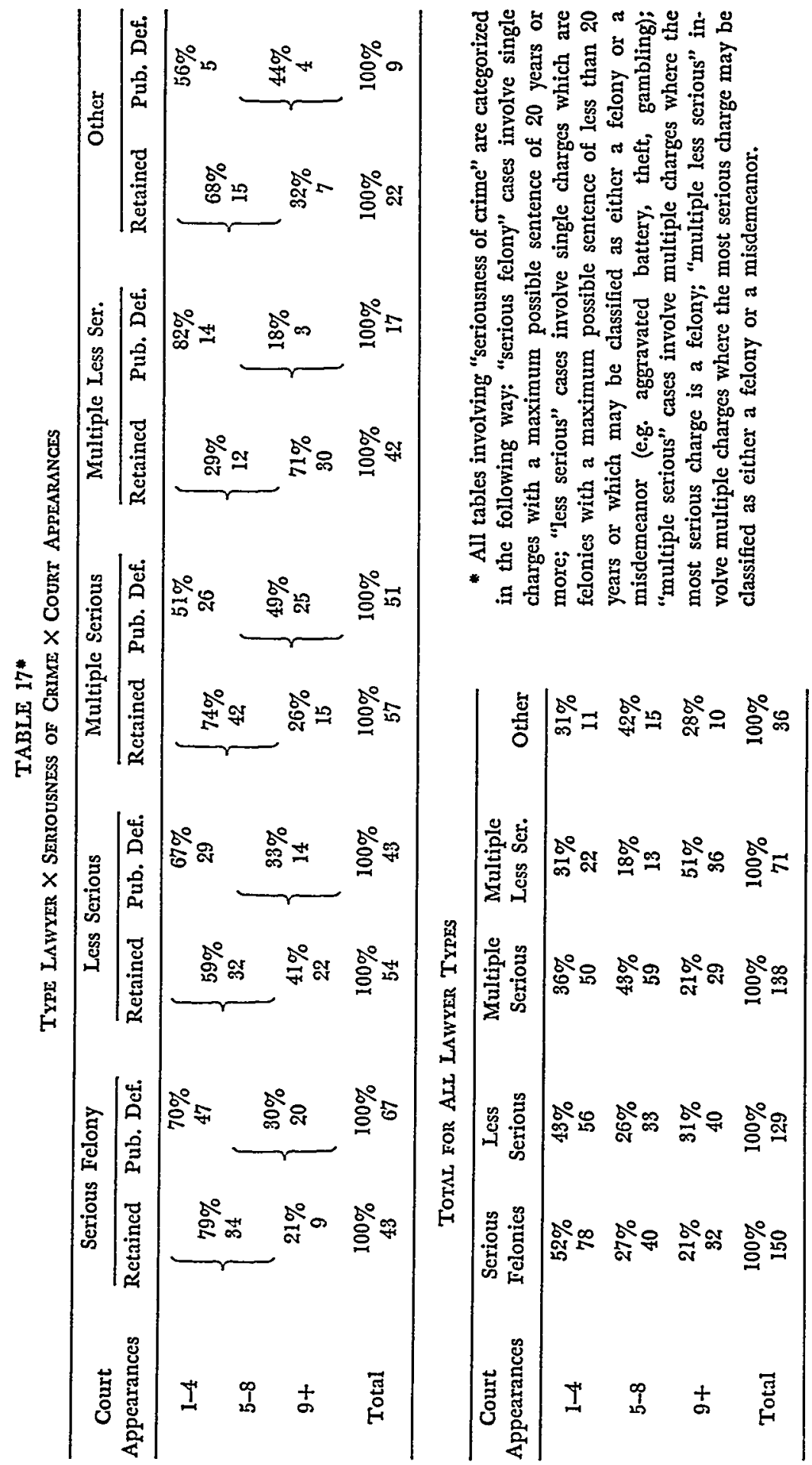




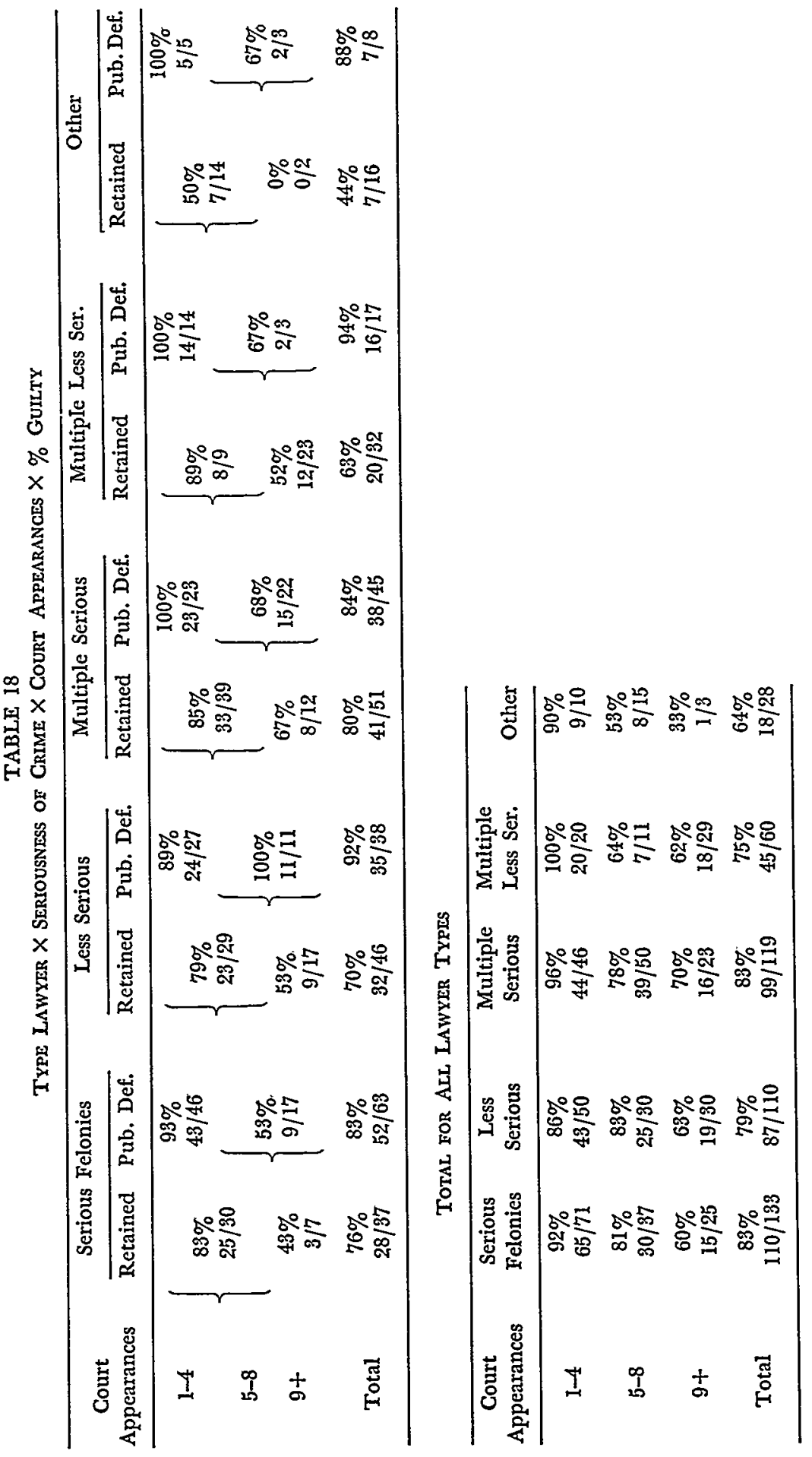




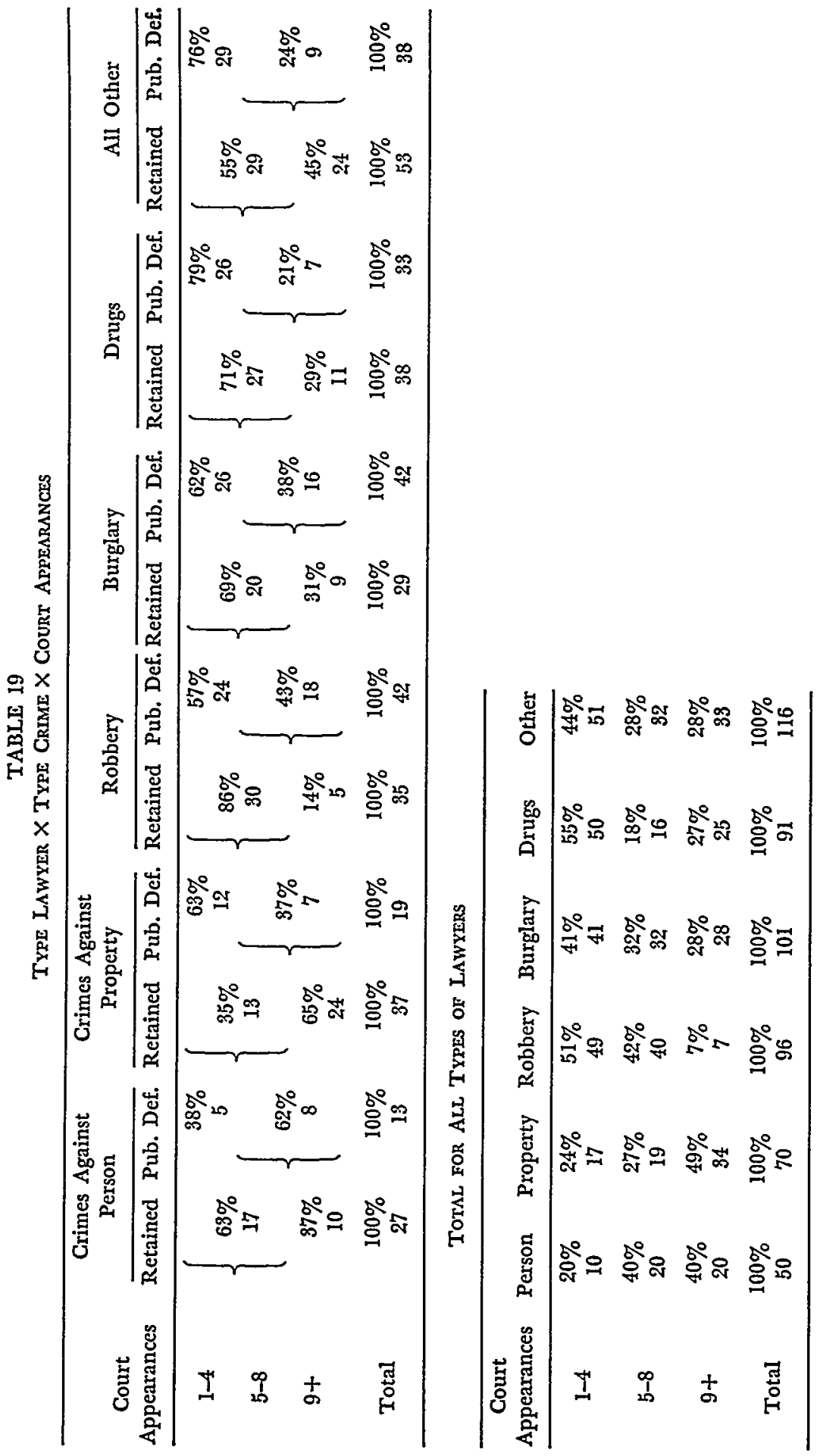




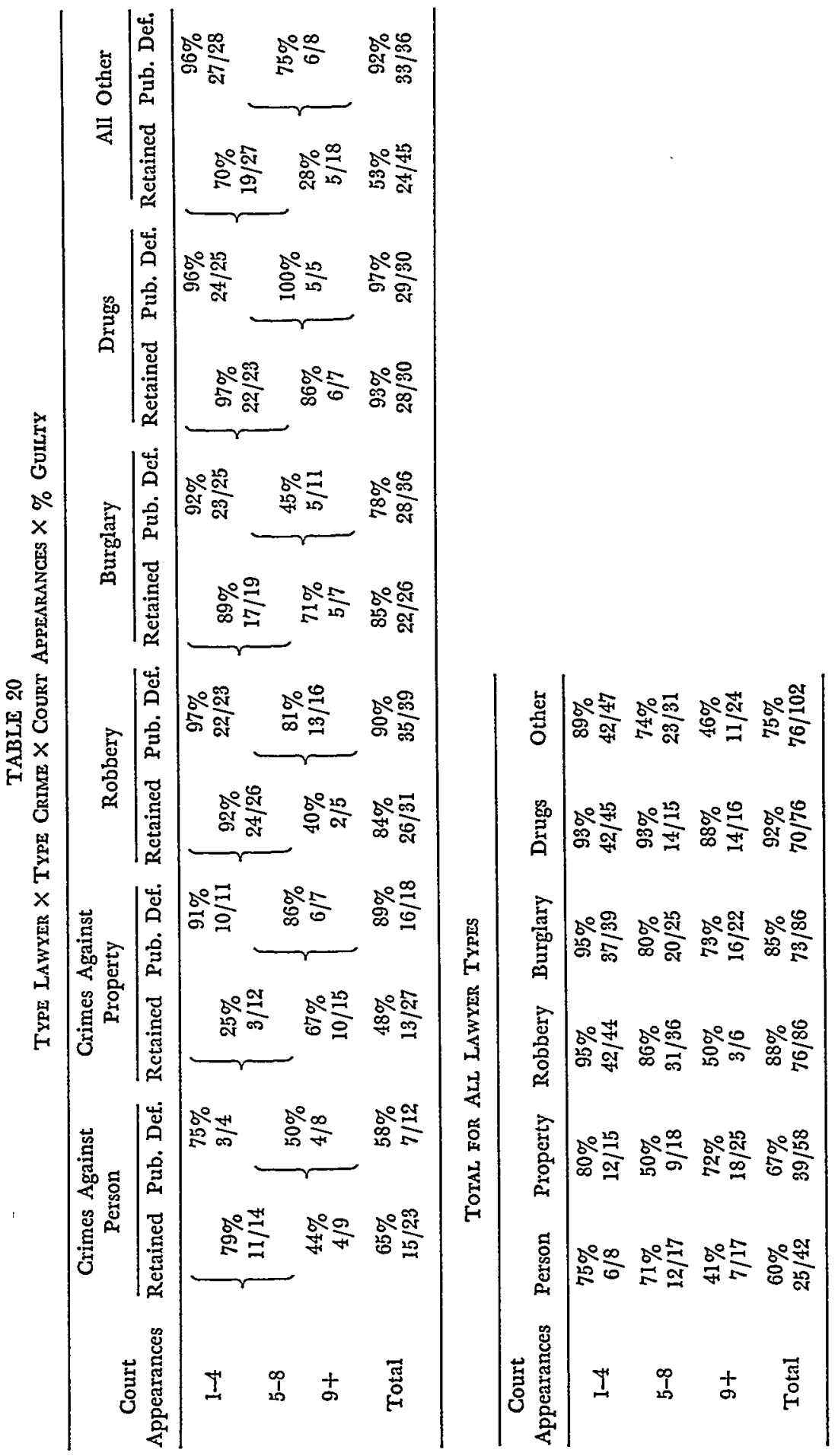


TABLE 21

Recorded Explanations for Continuances By Moving Party

\begin{tabular}{lccccccc}
\hline & $\begin{array}{c}\text { Retained } \\
\text { Lawyer }\end{array}$ & $\begin{array}{c}\text { Public } \\
\text { Defender }\end{array}$ & $\begin{array}{c}\text { Other } \\
\text { Lawyer }\end{array}$ & Court & $\begin{array}{c}\text { State's } \\
\text { Attorney }\end{array}$ & $\begin{array}{c}\text { By } \\
\text { Agree- } \\
\text { ment }\end{array}$ & $\begin{array}{c}\text { Party } \\
\text { Un- } \\
\text { known }\end{array}$ \\
\hline Explained & $30 \%$ & $56 \%$ & $57 \%$ & $54 \%$ & $32 \%$ & $32 \%$ & $57 \%$ \\
Not & 109 & 66 & 169 & 710 & 46 & 244 & 70 \\
Explained & $70 \%$ & $44 \%$ & $43 \%$ & $46 \%$ & $68 \%$ & $68 \%$ & $43 \%$ \\
& 258 & 51 & 128 & 598 & 98 & 529 & 52 \\
Total & $100 \%$ & $100 \%$ & $100 \%$ & $100 \%$ & $100 \%$ & $100 \%$ & $100 \%$ \\
& 367 & 117 & 297 & 1308 & 144 & 773 & 122 \\
\hline
\end{tabular}

TABLE 22

Type Lawyer $\times$ Median Number of Motions by EAch Party

\begin{tabular}{lcccc}
\hline & Retained & $\begin{array}{c}\text { Public } \\
\text { Defender }\end{array}$ & Other & Total \\
\hline Defendant & 1.9 & 0.8 & 2.2 & 1.4 \\
Court & 2.3 & 2.0 & 2.7 & 2.2 \\
State & 0.6 & 0.6 & 0.6 & 0.6 \\
By Agreement & 1.8 & 0.7 & 1.5 & 1.0 \\
Not Available & 0.6 & 0.6 & 0.7 & 0.6 \\
Total & 7.2 & 4.7 & 7.7 & 5.8 \\
\hline
\end{tabular}

TABLE 23

Type LAwyer $\times$ Prior Record* $\times$ Court Appearances

\begin{tabular}{|c|c|c|c|c|c|c|}
\hline \multirow{2}{*}{$\begin{array}{c}\text { Court } \\
\text { Appearances }\end{array}$} & \multicolumn{2}{|c|}{ Retained Lawyer } & \multicolumn{2}{|c|}{ Public Defender } & \multicolumn{2}{|c|}{$\begin{array}{l}\text { Total for All } \\
\text { Lawyer Types }\end{array}$} \\
\hline & No Record & Record & No Record & Record & No Record & Record \\
\hline $1-4$ & $\begin{array}{c}30 \% \\
56\end{array}$ & $\begin{array}{l}45 \% \\
15\end{array}$ & $\begin{array}{c}63 \% \\
97\end{array}$ & $\begin{array}{l}75 \% \\
24\end{array}$ & $\begin{array}{l}39 \% \\
173\end{array}$ & $\begin{array}{l}51 \% \\
44\end{array}$ \\
\hline $5-8$ & $\begin{array}{c}29 \% \\
54\end{array}$ & $\begin{array}{l}33 \% \\
11\end{array}$ & $\begin{array}{c}28 \% \\
43\end{array}$ & $\begin{array}{c}19 \% \\
6\end{array}$ & $\begin{array}{l}32 \% \\
139\end{array}$ & $\begin{array}{l}24 \% \\
21\end{array}$ \\
\hline $9+$ & $\begin{array}{l}41 \% \\
76\end{array}$ & $\begin{array}{c}21 \% \\
7\end{array}$ & $\begin{array}{c}10 \% \\
15\end{array}$ & $\begin{array}{l}6 \% \\
2\end{array}$ & $\begin{array}{l}29 \% \\
126\end{array}$ & $\begin{array}{l}24 \% \\
21\end{array}$ \\
\hline Total & $\begin{array}{l}100 \% \\
186\end{array}$ & $\begin{array}{c}100 \% \\
38\end{array}$ & $\begin{array}{l}100 \% \\
155\end{array}$ & $\begin{array}{c}100 \% \\
32\end{array}$ & $\begin{array}{c}100 \% \\
438\end{array}$ & $\begin{array}{c}100 \% \\
86\end{array}$ \\
\hline
\end{tabular}

"This table is divided into categories of "record" and "no record." "No record" does not necessarily mean that the defendant had not been previously convicted. It means that the case file did not indicate a prior record. The difference is significant and may account for what appears to be a defendant population with a low rescidivist rate. 
TABLE 24

BaIl Status $\times$ Court Appearances

\begin{tabular}{cccc}
\hline $\begin{array}{c}\text { Court } \\
\text { Appearances }\end{array}$ & Bailed & Jailed & Not Available \\
\hline \multirow{2}{*}{$1-4$} & $32 \%$ & $44 \%$ & $58 \%$ \\
& 78 & 78 & 61 \\
$5-8$ & $29 \%$ & $35 \%$ & $27 \%$ \\
& 70 & 62 & 28 \\
$9-12$ & $20 \%$ & $12 \%$ & $4 \%$ \\
& 49 & 22 & 4 \\
$13+$ & $19 \%$ & $8 \%$ & $11 \%$ \\
& 45 & 15 & 12 \\
Total & $100 \%$ & $100 \%$ & $100 \%$ \\
& 242 & 177 & 105 \\
\hline
\end{tabular}

TABLE 25

Barl Status $\times \%$ Guilty $\times$ Court appearances

\begin{tabular}{cccc}
\hline $\begin{array}{c}\text { Court } \\
\text { Appearances }\end{array}$ & Bailed & Jailed & Not Available \\
\hline \multirow{2}{*}{$1-4$} & $86 \%$ & $93 \%$ & $98 \%$ \\
& $63 / 73$ & $62 / 67$ & $56 / 57$ \\
$5-8$ & $71 \%$ & $83 \%$ & $73 \%$ \\
& $45 / 63$ & $45 / 54$ & $19 / 26$ \\
$9-12$ & $68 \%$ & $71 \%$ & $75 \%$ \\
& $28 / 41$ & $12 / 17$ & $3 / 4$ \\
$13+$ & $70 \%$ & $83 \%$ & $0 \%$ \\
& $21 / 30$ & $5 / 6$ & $0 / 12$ \\
Total & $76 \%$ & $86 \%$ & $79 \%$ \\
& $157 / 207$ & $124 / 144$ & $78 / 99$ \\
\hline
\end{tabular}

TABLE 26

Race $\times$ BaIl Status $\times$ Court Appearances

\begin{tabular}{|c|c|c|c|c|c|}
\hline \multirow{2}{*}{$\begin{array}{c}\text { Court } \\
\text { Appearances }\end{array}$} & \multicolumn{2}{|c|}{ Bailed } & \multicolumn{2}{|c|}{ Tailed } & \multirow{2}{*}{$\begin{array}{l}\text { Bail or } \\
\text { Race Not } \\
\text { Available }\end{array}$} \\
\hline & White & Non-White & White & Non-White & \\
\hline $1-4$ & $\begin{array}{c}26 \% \\
28\end{array}$ & $\begin{array}{c}40 \% \\
47\end{array}$ & $\begin{array}{l}41 \% \\
24\end{array}$ & $\begin{array}{c}48 \% \\
53\end{array}$ & $\begin{array}{c}50 \% \\
65\end{array}$ \\
\hline $5-8$ & $\begin{array}{c}31 \% \\
34\end{array}$ & $\begin{array}{c}31 \% \\
36\end{array}$ & $\begin{array}{l}33 \% \\
19\end{array}$ & $\begin{array}{c}36 \% \\
40\end{array}$ & $\begin{array}{c}24 \% \\
31\end{array}$ \\
\hline $9-12$ & $\begin{array}{c}23 \% \\
25\end{array}$ & $\begin{array}{c}19 \% \\
23\end{array}$ & $\begin{array}{l}17 \% \\
10\end{array}$ & $\begin{array}{l}9 \% \\
10\end{array}$ & $\begin{array}{c}5 \% \\
7\end{array}$ \\
\hline $13+$ & $\begin{array}{c}19 \% \\
21\end{array}$ & $\begin{array}{c}10 \% \\
12\end{array}$ & $\begin{array}{l}9 \% \\
5\end{array}$ & $\begin{array}{c}7 \% \\
8\end{array}$ & $\begin{array}{c}20 \% \\
26\end{array}$ \\
\hline Total & $\begin{array}{c}100 \% \\
108\end{array}$ & $\begin{array}{c}100 \% \\
118\end{array}$ & $\begin{array}{c}100 \% \\
58\end{array}$ & $\begin{array}{c}100 \% \\
111\end{array}$ & $\begin{array}{c}100 \% \\
129\end{array}$ \\
\hline
\end{tabular}


TABLE 27

RACE $\times$ COURT APpEARANCES

\begin{tabular}{cccc}
\hline $\begin{array}{c}\text { Court } \\
\text { Appearances }\end{array}$ & White & Non-White & Not Available \\
\hline \multirow{2}{*}{$1-4$} & $35 \%$ & $49 \%$ & $15 \%$ \\
& 72 & 140 & 5 \\
$5-8$ & $33 \%$ & $31 \%$ & $9 \%$ \\
& 68 & 89 & 3 \\
$9-12$ & $17 \%$ & $13 \%$ & $9 \%$ \\
& 36 & 36 & 3 \\
$13+$ & $15 \%$ & $7 \%$ & $67 \%$ \\
& 30 & 20 & 22 \\
Total & $100 \%$ & $100 \%$ & $100 \%$ \\
& 206 & 285 & 33 \\
\hline
\end{tabular}

TABLE 28

Race $\times \%$ Guilty $\times$ Court Appearances

\begin{tabular}{cccc}
\hline $\begin{array}{c}\text { Court } \\
\text { Appearances }\end{array}$ & White & Non-White & Not Available \\
\hline \multirow{2}{*}{$1-4$} & $88 \%$ & $95 \%$ & $67 \%$ \\
& $57 / 65$ & $122 / 129$ & $2 / 3$ \\
$5-8$ & $67 \%$ & $83 \%$ & $100 \%$ \\
& $42 / 63$ & $65 / 78$ & $2 / 2$ \\
$9-12$ & $55 \%$ & $83 \%$ & $100 \%$ \\
& $17 / 31$ & $25 / 30$ & $1 / 1$ \\
$13+$ & $62 \%$ & $92 \%$ & $7 \%$ \\
& $13 / 21$ & $12 / 13$ & $1 / 14$ \\
Total & $72 \%$ & $90 \%$ & $30 \%$ \\
& $129 / 180$ & $224 / 250$ & $6 / 20$ \\
\hline
\end{tabular}




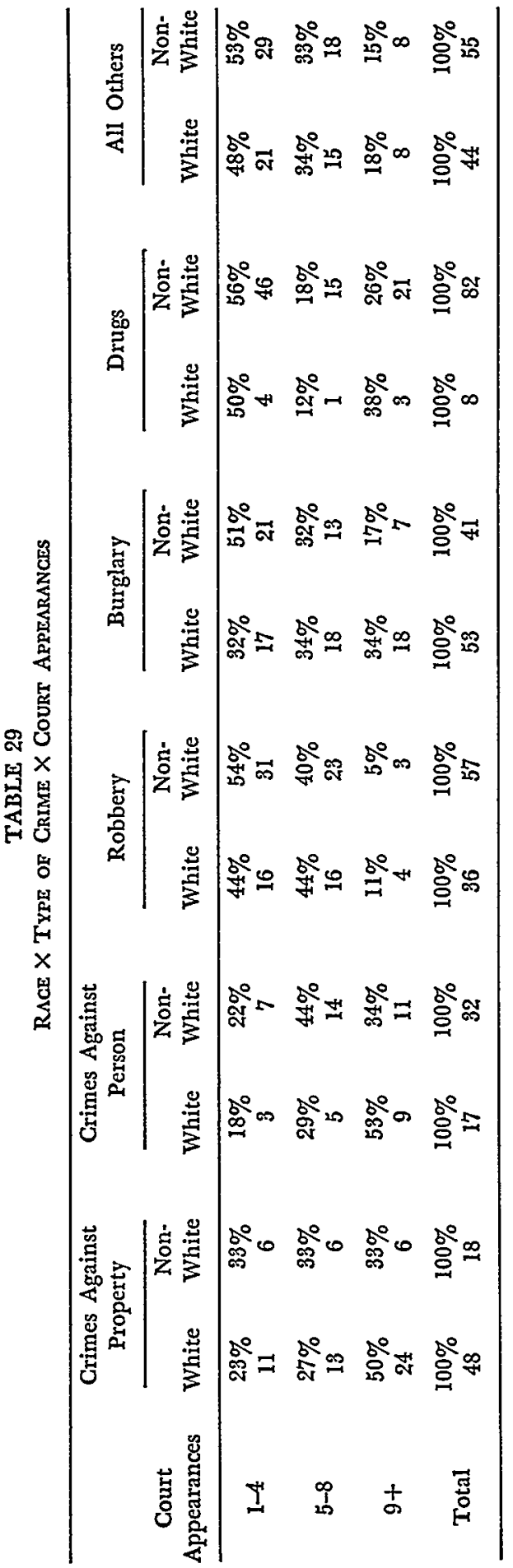

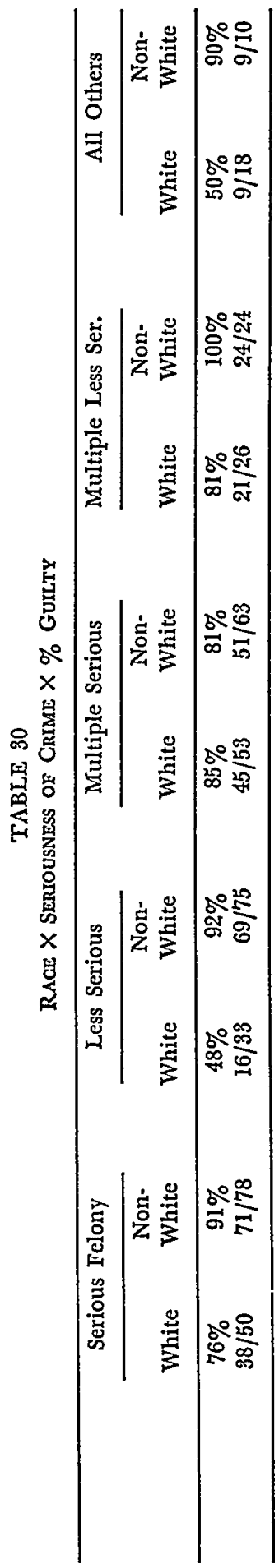




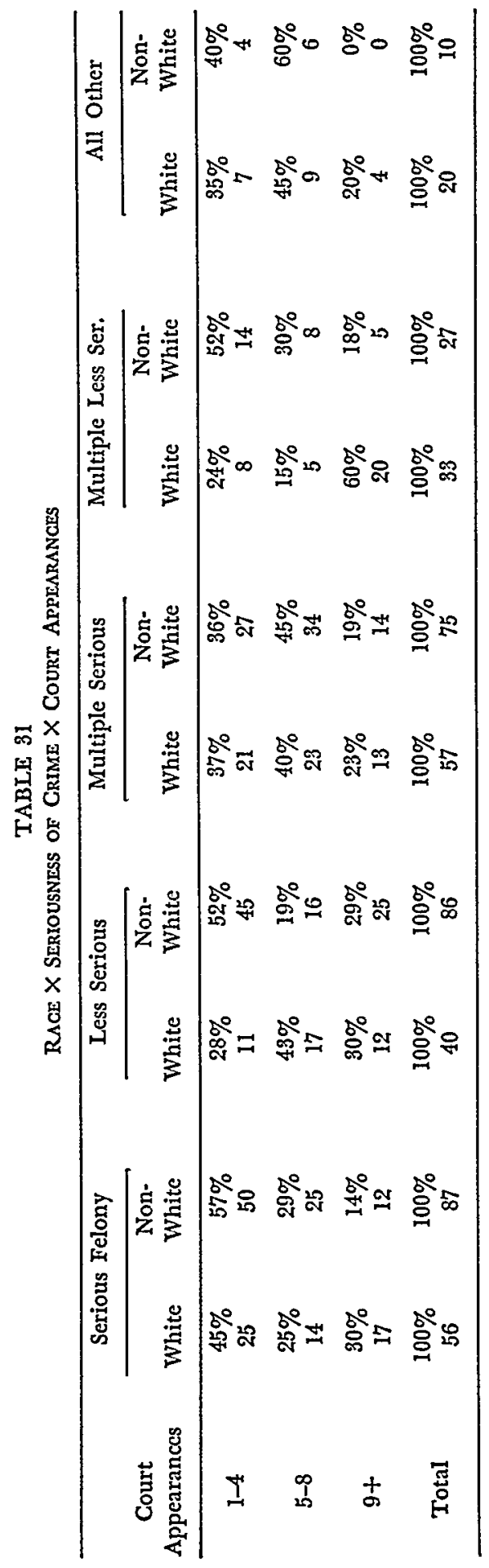


TABLE 32

Race $\times$ Charge Reduction [Among Those Found GuItTy]

\begin{tabular}{lccc}
\hline & No Reduction & Reduction & Total \\
\hline White & $88 \%$ & $12 \%$ & $100 \%$ \\
& 115 & 15 & 130 \\
Non-White & $77 \%$ & $23 \%$ & $100 \%$ \\
Race Not & 173 & 52 & 225 \\
Available & $67 \%$ & $33 \%$ & $100 \%$ \\
\hline
\end{tabular}

TABLE 33

RACE $\times$ TYPE SENTENGE

\begin{tabular}{lcccc}
\hline & Probation & $\begin{array}{c}\text { Probation } \\
\text { Prison }\end{array}$ & Prison & $\begin{array}{c}\text { Total } \\
\text { Guilty }\end{array}$ \\
\hline White & $24 \%$ & $18 \%$ & $58 \%$ & $100 \%$ \\
& 30 & 23 & 74 & 127 \\
Non-White & $25 \%$ & $21 \%$ & $55 \%$ & $100 \%$ \\
Race Not & 53 & 47 & 120 & 220 \\
Available & $17 \%$ & $0 \%$ & $83 \%$ & $100 \%$ \\
\hline
\end{tabular}

TABLE 34

Race $\times$ Length of Prison Sentence

\begin{tabular}{lccc}
\hline & $0-19$ Months & $20+$ Months & Total Guilty \\
\hline White & $68 \%$ & $32 \%$ & $100 \%$ \\
& 88 & 41 & 129 \\
Non-White & $64 \%$ & $36 \%$ & $100 \%$ \\
Race Not & 144 & 80 & 224 \\
Available & $67 \%$ & $33 \%$ & $100 \%$ \\
\hline
\end{tabular}

TABLE 35

Court Appearances $\times$ Length in Days [Preliminary Cases]

\begin{tabular}{crrrrrrrrrr}
\hline Court & $0-$ & $40-$ & $80-$ & $120-$ & $160-$ & $200-$ & $250-$ & $300-$ & $400-$ & \\
Appearances & 39 & 79 & 119 & 159 & 199 & 249 & 299 & 399 & 499 & Total \\
\hline $1-2$ & 311 & 20 & 2 & 1 & 10 & 2 & & 3 & 1 & 350 \\
$3-4$ & 19 & 57 & 27 & 14 & 4 & 4 & 3 & 12 & 2 & 142 \\
$5-6$ & & 3 & 11 & 23 & 8 & 4 & 2 & & 1 & 52 \\
$7-8$ & & & & 5 & 5 & 4 & & 1 & & 15 \\
$9-10$ & & & & & 1 & 7 & 2 & & & 10 \\
\hline
\end{tabular}

Median Days Pending $=27$. 
TABLE 36

Court appearanges $\times \%$ Guilty $*$ [Preliminary hearing Cases]

\begin{tabular}{ccc}
\hline Court & $\%$ \\
Appearances & Guilty \\
\hline \multirow{2}{*}{2} & $45 \%$ \\
& 2 & $93 / 208$ \\
& $3-4$ & $17 \%$ \\
& $5+$ & $22 \%$ \\
& $30 / 136$ \\
& $10 \%$ \\
& Total & $8 / 79$ \\
\end{tabular}

* All preliminary hearing tables reporting the conviction rate are based on the total number of preliminary hearing defendants for whom disposition information was available minus those defendants held over to the grand jury. Information was not available for 3 defendants; 9 defendants were held over to the grand jury.

TABLE 37

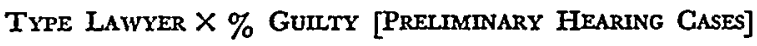

Retained Lawyer: $21 \%$ Guilty

All Others: $\quad 28 \%$ Guilty

TABLE 38

Type Lawyer $\times$ Court Appearances [Preliminary Hearing Cases]

\begin{tabular}{cccc}
\hline $\begin{array}{c}\text { Court } \\
\text { Appearances }\end{array}$ & Retained & All Other & Total \\
\hline 1 & $4 \%$ & $45 \%$ & $37 \%$ \\
& 5 & 205 & 210 \\
2 & $14 \%$ & $27 \%$ & $24 \%$ \\
& 16 & 124 & 140 \\
$3-4$ & $45 \%$ & $20 \%$ & $25 \%$ \\
& 51 & 92 & 143 \\
$5-6$ & $25 \%$ & $5 \%$ & $9 \%$ \\
& 28 & 24 & 52 \\
$7+$ & $12 \%$ & $3 \%$ & $5 \%$ \\
& 13 & 15 & 28 \\
Total & $100 \%$ & $100 \%$ & $100 \%$ \\
& 113 & 460 & 573 \\
\hline
\end{tabular}


TABLE 39

RACE $\times$ COURT APPEARANGES [PreIIMINARY CASES]

\begin{tabular}{|c|c|c|}
\hline $\begin{array}{c}\text { Court } \\
\text { Appearances }\end{array}$ & White & Negro \\
\hline 1 & $\begin{array}{c}29 \% \\
63\end{array}$ & $\begin{array}{l}43 \% \\
128\end{array}$ \\
\hline 2 & $\begin{array}{c}27 \% \\
59\end{array}$ & $\begin{array}{c}20 \% \\
60\end{array}$ \\
\hline $3-4$ & $\begin{array}{c}29 \% \\
63\end{array}$ & $\begin{array}{c}23 \% \\
68\end{array}$ \\
\hline $5+$ & $\begin{array}{c}16 \% \\
34\end{array}$ & $\begin{array}{c}14 \% \\
43\end{array}$ \\
\hline Total & $\begin{array}{l}100 \% \\
219\end{array}$ & $\begin{array}{l}100 \% \\
299\end{array}$ \\
\hline
\end{tabular}

TABLE 40

Race $\times$ Court Appearances $\times \%$ Guilty [Preliminary Cases]

\begin{tabular}{|c|c|c|}
\hline $\begin{array}{c}\text { Court } \\
\text { Appearances }\end{array}$ & White & Negro \\
\hline 1 & $\begin{array}{r}55 \% \\
34 / 62\end{array}$ & $\begin{array}{c}39 \% \\
50 / 127\end{array}$ \\
\hline 2 & $\begin{array}{r}7 \% \\
4 / 59\end{array}$ & $\begin{array}{r}27 \% \\
16 / 59\end{array}$ \\
\hline $3-4$ & $\begin{array}{r}22 \% \\
13 / 58\end{array}$ & $\begin{array}{r}23 \% \\
15 / 66\end{array}$ \\
\hline $5+$ & $\begin{array}{r}6 \% \\
2 / 33\end{array}$ & $\begin{array}{l}14 \% \\
6 / 42\end{array}$ \\
\hline Total & $\begin{array}{c}25 \% \\
53 / 212\end{array}$ & $\begin{array}{c}30 \% \\
87 / 294\end{array}$ \\
\hline
\end{tabular}

